

\section{The impact of long-term biosolids application (>100 years) on soil metal dynamics}

Abdul-Wahab Mossa, Elizabeth H. Bailey, Abida Usman, Scott D. Young*, Neil M. J. Crout

School of Biosciences, University of Nottingham, Sutton Bonington Campus, Leicestershire LE12 5RD, UK

* Corresponding author, E-mail address: scott.young@nottingham.ac.uk 
1 The impact of long-term biosolids application (>100 years) on soil metal 2 dynamics

3 Abdul-Wahab Mossa, Elizabeth H. Bailey, Abida Usman, Scott D. Young*, Neil M. J. Crout

4 School of Biosciences, University of Nottingham, Sutton Bonington Campus, Leicestershire

5 LE12 5RD, UK

$6 *$ Corresponding author, E-mail address: scott.young@nottingham.ac.uk

\section{Abstract}

8 Biosolids application to arable land is a common, and cost-effective, practice but the impact of

9 prolonged disposal remains uncertain. We evaluated the dynamics of potentially toxic elements 10 (PTEs) at a long-established 'dedicated' sewage treatment farm. Soil metal concentrations 11 exceeded regulations governing application of biosolids to non-dedicated arable land. 12 However, measurement of isotopic exchangeability of $\mathrm{Ni}, \mathrm{Cu}, \mathrm{Zn}, \mathrm{Cd}$ and $\mathrm{Pb}$ demonstrated support for the 'protection hypothesis' in which biosolids constituents help immobilise potential toxic metals (PTMs). Metal concentrations in a maize crop were strongly, and almost equally, correlated with all 'capacity-based' and 'intensity-based' estimates of soil metal

16 bioavailability. This was attributable to high correlations between soil factors controlling

17 bioavailability (organic matter, phosphate etc.) on a site receiving a single source of PTMs.

18 Isotopic analysis of the maize crop suggested contributions to foliar $\mathrm{Pb}$ from soil dust

19 originating from neighbouring fields. There was also clear evidence of metal-specific effects

20 of biosolids on soil metal lability. With increasing metal concentrations there was both

21 decreasing lability of $\mathrm{Cd}$ and $\mathrm{Pb}$, due to interaction with increasing phosphate concentrations,

22 and increasing lability of $\mathrm{Ni}, \mathrm{Cu}$ and $\mathrm{Zn}$ due to weaker soil binding. Such different responses

23 to prolonged biosolids disposal to arable soil should be considered when setting regulatory

24 limits. 
25 Keywords: Biosolids; metal lability, trace elements; lead isotopes; isotopic dilution 


\section{Introduction}

27 Application of biosolids to arable soil is currently the preferred disposal method. This is partly because it is cost effective compared with alternative methods: the cost is approximately 30$50 \%$ lower than landfilling or incineration (Antille et al., 2017). Moreover, recycling plant nutrients and organic matter make the use of biosolids in agriculture an environmentally favourable option in comparison to other management options (Mamindy-Pajany et al., 2014; Samaras et al., 2008; Wang et al., 2008). However, contamination of sewerage systems with potentially toxic elements (PTEs), such as $\mathrm{Cd}, \mathrm{Zn}, \mathrm{Cu}$ and $\mathrm{Pb}$, diminishes the beneficial impact of biosolids and presents a significant environmental burden (Hernandez-Soriano and JimenezLopez, 2012; Roig et al., 2012; Singh and Agrawal, 2008).

Ample research has indicated that a variety of soil properties alter metal bioavailability (Rosenfeld et al., 2018). Therefore, assessment of metal contamination based solely on total soil metal concentration is a poor indicator of environmental impact (Meers et al., 2007). This is particularly relevant in biosolid-amended soils where contaminants are introduced into soils already in association with adsorptive organic and inorganic phases. This limits the environmental risks of these contaminants and forms the basis of the "protection hypothesis" (Mamindy-Pajany et al., 2014). On the other hand, organic matter mineralization (post application) could result in the release of contaminants into more bioavailable forms over long periods of biosolids application - a concept loosely labelled the "time bomb hypothesis" (Stietiya and Wang, 2011).

Some studies suggest that the free ion activity (FIA) of divalent metal cations in the soil solution is the best indicator of PTE bioavailability (Hooda, 2010; Tye et al., 2003). The FIA will depend on the soil characteristics which control the solid $\rightleftharpoons$ solution equilibrium of labile PTEs (Groenenberg et al., 2017). Thus, estimating the labile pool in soil may enable a more 
accurate assessment of toxicity and risk from PTEs. The 'labile' pool of metal is the fraction of soil metal that forms an equilibrium between the solid and solution phases within a short time scale; see for example Groenenberg et al., (2017). Whilst chemical extractions have been traditionally used to quantify available metal (Kim et al., 2015), it is acknowledged that these extractions are operationally defined and can be poorly selective (Young et al., 2005). Other limitations include re-adsorption processes during extraction or overestimation of lability due to the dissolution of mineral surfaces thereby releasing non-labile metal (Marzouk et al., 2013a; Young et al., 2005). The isotopic dilution technique has been recognised as a more robust and mechanistically based method that reliably quantifies the labile reservoir of metal in soil (Hamon et al., 2008; Stacey et al., 2001). The technique is based on the premise that when a known amount of a tracer isotope of a metal is introduced into a soil suspension, its solid:solution ratio mirrors that of the native reactive metal. Thus, the ratio of the tracer isotope to that of the indigenous isotope in solution can be used to calculate the size of the soil metal labile pool (also termed the E-value or isotopically exchangeable fraction) (Hamon et al., 2008;

64 Stacey et al., 2001).

The aim of this study was to assess the consequences of long-term application of biosolids to arable soils. The specific objectives were to determine: (i) solubility of PTEs, (ii) the 'reactivity' of soil PTE reservoir and (iii) transfer of PTEs to agricultural crops at a longestablished sewage treatment farm in the UK.

\section{Materials and methods}

\subsection{Location and sample collection.}

71 Soil and plant samples $(\mathrm{n}=38)$ were collected on $7^{\text {th }}$ and $8^{\text {th }}$ of August 2013 from 31 fields of a sewage processing farm (c. 700 ha) in the East Midlands of England that has been in use for over 100 years. At the time of sampling ( $\mathrm{n}=31$ fields), the site was used to grow feedstock 
74 (nine varieties of fodder maize; Table S1) for biogas production. The practice is to ensile the maize prior to use for gas production and residues are returned to the arable fields. No produce from the farm is used for human or animal consumption; the facility operates under a U.K. DEFRA (Department for Environment, Food \& Rural Affairs) licence as a 'dedicated site'. It is worth noting that the site is a fully operational disposal site with more than 60 individual fields, each of which carries the imprint of urban biosolids disposal, and the facility has been used for more than a century. Therefore, even though there are no audits of biosolids composition or disposal rate, the range of biosolids application across the site is evident from the range of metal concentrations in soil, for example the concentration of $\mathrm{Zn}$ ranges from near background concentration $\left(122 \mathrm{mg} \mathrm{kg}^{-1}\right)$ to heavily contaminated $\left(>2000 \mathrm{mg} \mathrm{kg}^{-1}\right)$. The variation in soil organic matter content, phosphate concentration and metal concentrations undoubtedly represent the historical imprint of past biosolids applications and provide unique evidence for testing the two confounding hypotheses surrounding the use of biosolids in agricultural soils. The invaluable advantage of using the site is its longevity - a feature which is key to examining the long term effects and which provides considerable advantages over short-term (but controlled) trials with biosolids disposal to soil.

Four maize plants were cut 3-4 cm above ground level from within one square metre in each field. Four soil samples $(0-20 \mathrm{~cm})$ were taken within rows inside the same square metre area and mixed into one composite sample. Leaves were removed from the maize stems and both leaves and stems were washed with tap water, followed by deionised water, and then ovendried at $60{ }^{\circ} \mathrm{C}$ for four days. Stems and leaves were ground and combined into one composite sample using a cutting mill (Retsch, Model SM 100) and ultra-centrifugal mill with titanium screen (Retsch, Model ZM 200), prior to analysis. Soil samples were sieved to $<4 \mathrm{~mm}$, airdried and a subsample (c. 20 g) was agate ball-milled (Retsch, Model PM 400) prior to analysis of carbon, free oxides and total elemental concentrations. 


\subsection{Plant material digestion and analysis}

100 A portion of finely ground plant material (c. $200 \mathrm{mg}$ ) was digested with $6 \mathrm{~mL}$ of concentrated

101 Primar grade $\mathrm{HNO}_{3}$ using a Multiwave PRO Anton Paar microwave reaction system, with 102 heating at $140^{\circ} \mathrm{C}$ for 20 minutes. Elemental analysis was by ICP-MS (Model iCapQ, Thermo 103 Scientific, Bremen). To assess the accuracy and precision of the digestion and analysis, a 104 standard reference material, NIST 1573a Tomato Leaves (National Institute of Standards and

105 Technology), and 3 operational blanks, were included in each sample batch. The elemental 106 recoveries for the certified reference material were $120 \% \pm 0.61 \%, 96.1 \% \pm 5.05 \%, 99.3 \% \pm$ $1074.50 \%$, and $103 \% \pm 7.21 \%$ for $\mathrm{Ni}, \mathrm{Cu}, \mathrm{Zn}$, and $\mathrm{Cd}$ respectively.

\subsection{Soil characterization}

109 Soil $\mathrm{pH}$ was determined in a suspension with Milli-Q water $(18.2 \mathrm{M} \Omega \mathrm{cm} ; 1: 2.5 \mathrm{~m} / \mathrm{v})$ after

110 shaking for 30 minutes on an end-over-end shaker; the measurement was repeated in $0.01 \mathrm{M}$

$111 \mathrm{Ca}\left(\mathrm{NO}_{3}\right)_{2}(1: 10 \mathrm{~m} / \mathrm{v})$ suspensions. Soil organic matter was estimated from loss on ignition $(\%$

112 LOI): approximately $5 \mathrm{~g}$ of oven-dried soil $(<4 \mathrm{~mm})$ was ignited in a muffle furnace at $550{ }^{\circ} \mathrm{C}$

113 for 4 hours. Available P (Olsen-P) in soil was estimated using the bicarbonate extraction

114 method described by Olsen et al., (1954) followed by colorimetric analysis adapted from

115 Murphy and Riley, (1962). Approximately $2.0 \mathrm{~g}$ of soil was weighed into $50 \mathrm{~mL}$ centrifuge

116 tubes with approximately $0.3 \mathrm{~g}$ of low phosphate charcoal and $30 \mathrm{~mL}$ of $0.5 \mathrm{M}$ sodium

117 bicarbonate. Samples were shaken end-over-end shaken for 30 minutes before centrifuging at

$1182500 \mathrm{~g}$ for 15 minutes. An aliquot of the extracted supernatant was added to $2 \mathrm{~mL} 3 \mathrm{M} \mathrm{H}_{2} \mathrm{SO}_{4}$

119 to neutralise the $\mathrm{NaHCO}_{3}$, followed by $4 \mathrm{~mL}$ of acid molybdate reagent and $4 \mathrm{~mL}$ of ascorbic

120 acid as a reducing agent; the final volume was made up to $50 \mathrm{~mL}$ with Milli-Q water. The

121 colour was allowed to develop for 20 minutes and absorbance read at $880 \mathrm{~nm}$ in a spectrophotometer (Model Ce1011, Cecil Instruments, Cambridge, UK). Samples were run in triplicates. Estimates of total $\mathrm{Al}, \mathrm{Fe}$ and $\mathrm{Mn}$ oxides were determined using the Dithionite- 
124 Citrate-Bicarbonate (DCB) extraction method (Anschutz et al., 1998). Finely ground soil

$125(0.250 \mathrm{mg})$ was shaken with $20 \mathrm{~mL} \mathrm{DCB}$ reagent at $20{ }^{\circ} \mathrm{C}$ and the concentrations of $\mathrm{Al}, \mathrm{Mn}$,

126 Fe in solution were determined by ICP-MS after centrifuging and syringe filtration $(<0.22 \mu \mathrm{m})$.

$127 \quad$ 2.3.1. Total elemental concentrations in soil $\left(M_{\text {Total }}\right)$

128 Approximately $200 \mathrm{mg}$ of finely ground soil was digested in a mixture of $\mathrm{HNO}_{3}, \mathrm{HClO}_{4}$, and

129 HF acids in a heating block digester prior to analysis by ICP-MS. Approximately $200 \mathrm{mg}$ of

130 finely ground soil were digested with $2 \mathrm{~mL}$ of $\mathrm{HNO}_{3}(70 \%$ trace element grade) and $1 \mathrm{~mL}$ of

$131 \mathrm{HClO}_{4}\left(70 \%\right.$ analytical grade) at $80{ }^{\circ} \mathrm{C}$ for $8 \mathrm{~h}$ followed by $2 \mathrm{~h}$ of heating at $100{ }^{\circ} \mathrm{C}$. This was

132 followed by addition of $2.5 \mathrm{~mL}$ of $\mathrm{HF}\left(40 \%\right.$ trace element grade) and heating at $120^{\circ} \mathrm{C}$ for $8 \mathrm{~h}$

133 to dryness. A further $2.5 \mathrm{~mL}$ of $\mathrm{HNO}_{3}$ and $2.5 \mathrm{~mL}$ of Milli-Q water were then added to the

134 dried residue and the vessels were heated at $50{ }^{\circ} \mathrm{C}$ for $30 \mathrm{~min}$. After the digestion was complete

135 the final volume was made up to $50 \mathrm{~mL}$ using Milli-Q water. The reference material NIST

136 2711a Montana soil, (National Institute of Standards and Technology) was used to ensure QA

137 and 10 operational blank digestions were used to estimate limits of detection (LOD). The

138 recoveries for the certified reference material were $86.7 \% \pm 1.72 \%, 105 \pm 1.90 \%, 102 \% \pm$

$1391.38 \%, 114 \% \pm 2.09 \%$, and $107 \% \pm 2.82 \%$ for $\mathrm{Ni}, \mathrm{Cu}, \mathrm{Zn}, \mathrm{Cd}$ and $\mathrm{Pb}$ respectively.

$140 \quad$ 2.3.2. Soluble metal concentrations $\left(M_{\text {soln }}\right)$

141 Dissolved trace and major metallic elements were determined on soil suspensions in $0.01 \mathrm{M}$

$142 \mathrm{Ca}\left(\mathrm{NO}_{3}\right)_{2}$ (1:10 soil:solution ratio) following 3 days equilibration time on an end-over-end

143 shaker. Following measurement of suspension $\mathrm{pH}$, the soil aqueous phase was isolated by

144 centrifugation $(2200 \mathrm{~g})$ and filtration $(0.22 \mu \mathrm{m}$ syringe filters $)$ prior to elemental analysis by

145 ICP-MS and determination of dissolved organic and inorganic carbon using a Shimadzu TOC

$146-$ Vcp analyser.

$147 \quad$ 2.3.3. Isotopically exchangeable metal $\left(M_{E}\right)$ : 
148 The concentrations of isotopically exchangeable $\mathrm{Ni}, \mathrm{Cu}, \mathrm{Zn}, \mathrm{Cd}$ and $\mathrm{Pb}$ were determined as 149 described in Mossa et al., (2017). Briefly, soils were suspended in $0.01 \mathrm{M} \mathrm{Ca}\left(\mathrm{NO}_{3}\right)_{2}$ (3 g: 30

$150 \mathrm{~mL}$ ) and pre-equilibrated on an end-over-end shaker for 2 days. Suspensions were then spiked 151 with five enriched stable isotopes, ${ }^{62} \mathrm{Ni}^{2+},{ }^{65} \mathrm{Cu}^{2+},{ }^{70} \mathrm{Zn}^{2+},{ }^{108} \mathrm{Cd}^{2+}$ and ${ }^{204} \mathrm{~Pb}^{2+}$, and equilibrated 152 for a further three days. The solution phase was isolated by centrifuging ( $2200 \mathrm{~g}$ ) for $15 \mathrm{~min}$ 153 and syringe-filtration $(<0.22 \mu \mathrm{m})$ prior to determination of isotopic ratios $\left({ }^{62} \mathrm{Ni} /{ }^{60} \mathrm{Ni},{ }^{65} \mathrm{Cu} /{ }^{63} \mathrm{Cu}\right.$, ${ }^{70} \mathrm{Zn} /{ }^{66} \mathrm{Zn},{ }^{108} \mathrm{Cd} /{ }^{111} \mathrm{Cd},{ }^{204} \mathrm{~Pb} /{ }^{206} \mathrm{~Pb},{ }^{204} \mathrm{~Pb} /{ }^{207} \mathrm{~Pb}$, and ${ }^{204} \mathrm{~Pb} /{ }^{208} \mathrm{~Pb}$ ) by Q-ICP-MS (Model iCapQ, operated in 'collision cell with kinetic energy discrimination (KED) mode'. To minimize

157 plasma flicker noise, multiple runs (c. 10×100 sweeps) and short dwell times were employed.

158 To minimise mass bias, a correction factor was estimated at a regular interval throughout the analytical session (every 15 samples). The correction factor was defined as the ratio between the true isotopic ratio (expected) and the isotopic ratio in standard reference material NIST SRM-981 (lead wire). The correction factors were used to correct for mass bias and thereby convert intensity (CPS) ratios to true isotope ratios and calculate isotopic abundances of the spike isotopes. Each measurement was replicated twice, and the relative standard deviation was mostly less than $5 \%$. As the relative abundance of $\mathrm{Pb}$ isotope varies according to its sources, Two unspiked samples were used determine $\mathrm{Pb}$ isotopic ratio instead of relying on the relative abundance of naturally occurring isotopes. The concentrations of isotopically exchangeable

$167 \mathrm{Ni}, \mathrm{Cu}, \mathrm{Zn}, \mathrm{Cd}$, and $\mathrm{Pb},(E$ - values), were calculated from Equation 1 (Gäbler et al., 1999).

169 Where $\mathrm{M}_{\text {soil }}$ and $\mathrm{M}_{\text {spike }}$ are the average atomic mass metal in soils and spike solutions 170 respectively, $\mathrm{W}$ is the mass of the soil $(\mathrm{kg}), \mathrm{C}_{\text {spike }}$ is the gravimetric concentration $\left(\mathrm{mg} \mathrm{L}^{-1}\right)$ of 171 the metal in the spike solution, $\mathrm{V}_{\text {spike }}$ is the volume of spike added (L), IA is the isotopic 
172 abundance, $R_{s s}$ is the ratio of isotopic abundances for the two isotopes in the spiked soil

173 solution. The same experimental procedure was repeated for all soils using $10^{-5} \mathrm{M} \mathrm{Na} \mathrm{NDTA}_{2}$

174 as the suspending solution instead of $0.01 \mathrm{M} \mathrm{Ca}\left(\mathrm{NO}_{3}\right)_{2}$. This was in response to the extremely

175 low solubility of $\mathrm{Pb}$ in the soils (Atkinson et al., 2011); the $\mathrm{Pb}$ data $\left(\mathrm{Pb}_{E}\right)$ presented include

176 only $E$-values obtained using EDTA as the soil suspension matrix.

\section{$177 \quad$ 2.3.4. Soil solution speciation}

178 The geochemical model, WHAM VII (Tipping, 1994), was used to speciate Ni, Cu, Zn, Cd and

$179 \mathrm{~Pb}$ in the solution phase of the $0.01 \mathrm{M} \mathrm{Ca}\left(\mathrm{NO}_{3}\right)_{2}$ soil suspension that was used to determine $E$ -

180 values. Inputs to the model included cation and anion concentrations and $\mathrm{pH}$ in the $\mathrm{Ca}\left(\mathrm{NO}_{3}\right)_{2}$

181 suspension. The dissolved organic carbon (DOC) was converted to fulvic acid (FA)

182 concentration by assuming (i) a carbon content of $50 \%$ and (ii) that FA constituted $65 \%$ of

183 DOC (Buekers et al., 2008; Lofts et al., 2008; Marzouk et al., 2013b). Partial pressure of $\mathrm{CO}_{2}$

$184\left(\mathrm{P}_{\mathrm{CO} 2}\right)$ was set to $0.004 \mathrm{~atm}$ and the temperature was set to $25^{\circ} \mathrm{C}$.

$185 \quad$ 2.3.5. Lead isotopic composition analysis in soil and plant samples

186 Abundances of the $\mathrm{Pb}$ isotopes ${ }^{204} \mathrm{~Pb},{ }^{206} \mathrm{~Pb},{ }^{207} \mathrm{~Pb}$ and ${ }^{208} \mathrm{~Pb}$ were determined in soil and plant

187 acid digests by ICP-MS. Instrument parameters were 6000 quadrupole sweeps with a dwell time of $10 \mathrm{~ms}$ and a dead time correction factor of $34.7 \mathrm{~ns}$. To ensure that the detector remained within the range of pulse-counting mode, all soil digests were diluted to a uniform $\mathrm{Pb}$ concentration of $10 \mu \mathrm{g} \mathrm{L}^{-1}$ with Milli-Q water. This was not possible for plant digests, which

191 were simply diluted to a $\mathrm{HNO}_{3}$ concentration of 3\% using Milli-Q water. Isobaric interference

192 from ${ }^{204} \mathrm{Hg}$ was corrected by measuring ${ }^{202} \mathrm{Hg}$. Thallium $\left({ }^{203} \mathrm{Tl},{ }^{205} \mathrm{Tl}\right)$ was used as an internal mass bias correction (MBC) and NIST-981 was then used to refine the MBC, as described by

194 Usman et al. (Usman et al., 2018). The NIST-981 standard was run after every 10 samples.

\subsection{Data analysis}


Multiple regression analysis was utilised to explore the effect of soil properties on metal solubility and lability. All variables, apart from $\mathrm{pH}$, included in the multiple regression were tested for normality and log-transformed when required. All statistical analysis were performed using R (R Core Team, 2018).

\section{Results and discussion}

\subsection{General characterization of the site}

202 General characteristics of soils used in the study are given in Table S2. Soil $\mathrm{pH}_{\mathrm{Ca}}, \mathrm{pH}$ measured in the solution phase of the $0.01 \mathrm{M} \mathrm{Ca}\left(\mathrm{NO}_{3}\right)_{2}$ suspensions, showed near-neutral values with very little variation across the soil dataset (5.95-6.94). Loss on ignition (LOI), covered a broad range 3.52-23.4\% (Table 1). As expected in biosolids-amended soils, total P concentrations were positively correlated with LOI $(\mathrm{r}=0.98 ; \mathrm{p}<0.001)$ and varied widely from 0.945 to 13.7 $\mathrm{g} \mathrm{kg}^{-1}$. The concentration of total free oxides in soil (DCB extraction) were variable, with ranges of 1.49-7.29 $\mathrm{g} \mathrm{kg}^{-1}, 0.24-2.82 \mathrm{~g} \mathrm{~kg}^{-1}$, and 10.9-36.3 $\mathrm{mg} \mathrm{kg}^{-1}$ for $\mathrm{Al}, \mathrm{Mn}$ and $\mathrm{Fe}$ respectively. DOC concentration, in the solution phase of $0.01 \mathrm{M} \mathrm{Ca}\left(\mathrm{NO}_{3}\right)_{2}$ suspensions, varied between $3.10-40.9 \mathrm{mg} \mathrm{L}^{-1}$, reflecting different histories of biosolids application.

\subsection{Enrichment factors}

212 An enrichment factor (EF) was used to reflect the status and the degree of pollution in soil.

213 Values of EF were determined after normalizing against Al following Eq. 2 (Bing et al., 2016;

214 Izquierdo et al., 2013):

$215 E F=\frac{\left(\frac{M e}{A l}\right) \text { sample }}{\left(\frac{M e}{A l}\right) \text { background }}$

216 Where $(\mathrm{Me} / \mathrm{Al})_{\text {sample }}$ is the concentration $\left(\mathrm{mg} \mathrm{kg}^{-1}\right)$ of an element relative to $\mathrm{Al}$ concentration

217 normalised to a similar ratio with the local background ratio (Me/Al) background. Background 218 concentrations used for comparison were median values for topsoils derived from the Triassic 
219 Mercian Mudstone of the UK (British Geological Survey, 2006; Izquierdo et al., 2013).

220 Sutherland. (2000) identified five contamination categories based on the enrichment factor:

$221 \mathrm{EF}<2$ depletion to minimal enrichment, $\mathrm{EF}=2-5$ : moderate enrichment, $\mathrm{EF}=5-20$ : significant 222 enrichment, $E F=20-40$ : very high enrichment, $E F>40$ extremely high enrichment. The majority 223 of elements had a mean EF greater than 5 reflecting significant enrichment (Fig S1).

\subsection{Total metal concentrations in soils}

Total metal concentrations in soil (M $\left.\mathrm{M}_{\text {Total }}\right)$ were strongly correlated with LOI $(\mathrm{r}=0.93-0.98, p$ $<0.001$, Table S3), suggesting a common source of contamination, consistent across all fields. Samples showed a wide range of $\mathrm{M}_{\text {Total, }}$, with $\mathrm{Zn}$ being the most abundant metal, with concentration spanning over one order of magnitude (122-2050 $\mathrm{mg} \mathrm{kg}^{-1}$ ); Cu ranged from 25.3 to $766 \mathrm{mg} \mathrm{kg}^{-1}$, $\mathrm{Cd}$ from 0.43 to $48.6 \mathrm{mg} \mathrm{kg}^{-1}$, $\mathrm{Cr}$ from 43.2 to $1670 \mathrm{mg} \mathrm{kg}^{-1}$, and $\mathrm{Pb}$ from 68.6 to $688 \mathrm{mg} \mathrm{kg}^{-1}$ (Fig. 1 and Table 1). The large variation in total soil metal concentration reflects variable biosolids application rates throughout the sampling area and the length of time that each field has been used for biosolids disposal. Values of $\mathrm{M}_{\text {Total }}$ in most fields exceeded the maximum permissible concentrations of metals in normal arable soils permitted by current regulations (The Sludge Use in Agriculture Regulations, 1989). However, it should be noted that the site is operated under licence from the Department of Environment Food \& Rural Affairs (DEFRA, U.K) and does not produce crops for human or animal consumption.

Figure 2 shows ratios between $\mathrm{Zn}$ and several metals $(\mathrm{Cr}, \mathrm{Cu}, \mathrm{Rb}$, and $\mathrm{Cd})$ in soils as a function of total soil $\mathrm{P}$ concentration $\left(\mathrm{P}_{\text {Total }}\right.$ ), which can be used as a reasonable proxy for biosolids loading. Rubidium was selected as a fingerprint for the presence of clays and therefore as an indication of native soil. Rubidium was used as a proxy for clay minerals based on (i) the fact that it is a common constituent of clay minerals (Kabata-Pendias and Pendias, 2001) and (ii) the assumption that the parent material is similar across the site. This is evidenced by the strong correlation between $\mathrm{Rb}$ and $\mathrm{Al}(\mathrm{r}=0.84)$ and $\mathrm{Cs}(\mathrm{r}=0.88)$ in these soils. Also biosolids are an 
unlikely source of $\mathrm{Rb}$, as indicated by the weakly negative correlation between $\mathrm{LOI}$ and $\mathrm{Rb}$ concentration in soil $(r=-0.37)$. Biosolids composition, leaching, and plant uptake are the main factors that most likely control the ratios between different metals in biosolids-amended soils. An attempt was made to estimate the annual loss through leaching and offtake by crop plants (Table 2). For metal loss through leaching, it was assumed that half of the annual rainfall (c. $600 \mathrm{~mm})$ was leached below the surface soil $(20 \mathrm{~cm})$. Metal concentration measured in 0.01 $\mathrm{M} \mathrm{Ca}\left(\mathrm{NO}_{3}\right)_{2}, \mathrm{M}_{\text {Soln }}$, was used as a proxy of metal concentration in the soil solution. Metal loss through crop harvest was based on metal concentration in the maize crop (above-ground biomass) assuming an annual yield of $10 \mathrm{tha}^{-1}$.

Notwithstanding the very crude assumptions underpinning the estimates in Table 2 it seems reasonable to conclude that metal losses through plant uptake and leaching are probably negligible and metals added with the sludge are largely conserved. Thus the relationships shown in Fig. 2 suggest that metal ratios in soil are mainly the result of differences in the ratios of the two end members - the native soil and the biosolids. The positive correlation between $\mathrm{Zn}: \mathrm{Rb}$ ratio and $\mathrm{P}_{\text {Total }}$ (Fig. 2A) indicates that biosolids application caused (i) increased $\mathrm{Zn}$ contents in soil and (ii) a dilution effect of native soil through increasing organic matter content, thus shifting $\mathrm{Zn}: \mathrm{Rb}$ to greater values. This is evidenced by a range of $0.76-1.55 \mathrm{EFs}$ for $\mathrm{Rb}$, indicating depletion to minimal enrichment. By contrast, the trends in Fig. 2(B-D) show that the ratios decrease towards an asymptote reflecting the composition of the applied sludge 263 integrated over time.

\section{$264 \quad$ 3.4. Changes in metal lability with sludge loading}

The $E$-values $\left(\mathrm{M}_{E}\right)$ of the studied metals spanned over two orders of magnitude (Table 3 ). $\mathrm{M}_{\text {Total }}$ was strongly correlated with $\mathrm{M}_{E}(r \geq 0.99$ for $\mathrm{Ni}, \mathrm{Cu}, \mathrm{Zn}$, and $\mathrm{Cd} ; r=0.72$ for $\mathrm{Pb})$. This is

267 probably the result of co-variance of the soil properties that are likely to affect metal lability 268 (e.g. soil organic matter, $\mathrm{pH}$ ) with biosolid application, coupled with the restricted range of $\mathrm{pH}$ 
across the site (Table 1). The ranges of metal lability $\left(\% \mathrm{M}_{E}\right)$ are shown in Table 3. Copper was the most labile metal and the lability decreased in the order $\mathrm{Cu}>\mathrm{Cd}>\mathrm{Zn} \approx \mathrm{Ni}>\mathrm{Pb}$. With the exception of $\mathrm{Ni}$, this order is in accordance with the findings of Garforth et al., (2016) who determined E-values for a single soil from the same site. In the present study $\% \mathrm{Ni}_{E}$ exhibited a 273 large variation (from 3.30 to $42.4 \%$ ); $\mathrm{Pb}$ was the least labile metal with an average $\% \mathrm{~Pb}_{E}$ of 2745.3 (Table 3).

Figure 3 shows metal lability $\left(\% \mathrm{M}_{E}\right)$ as a function of $\mathrm{P}_{\text {Total }}$. Nickel, $\mathrm{Cu}$, and $\mathrm{Cd}$ largely exhibited a single trend in which $\% \mathrm{M}_{E}$ increased with $\mathrm{P}_{\text {Total }}$ (i.e. metal loading from biosolids). Given the strong correlation between $\mathrm{M}_{\text {Total }}$ and $\mathrm{P}_{\text {Total }}\left(\right.$ Table S3), and $\mathrm{M}_{\text {Total }}$ and $\mathrm{M}_{\mathrm{E}}$, a clear trend in $\% \mathrm{M}_{\mathrm{E}}$ with $\mathrm{P}_{\text {Total }}$ was not anticipated. However, Figs $3 \mathrm{~A}-3 \mathrm{C}$ indicate that the interaction of metals with sludge-amended soil have a strong effect on metal lability; in the case of $\mathrm{Ni}, \mathrm{Cu}$, and $\mathrm{Zn}$ lability $\left(\% \mathrm{M}_{E}\right)$ increased with metal loading. This may be due to progressive occupancy of weaker binding sites on soil humus and metal oxides as metal concentration increases. By contrast, there was a clear decreasing trend with metal loading in the case of $\% \mathrm{Cd}_{E}$ and $\% \mathrm{~Pb}_{E}$. This is likely due to the high content of $\mathrm{P}$ on the site (up to $13,700 \mathrm{mg} \mathrm{kg}^{-1}$ ); correlations ( $r$ values) between $\mathrm{P}_{\text {Total }}$ and $\% \mathrm{Cd}_{\mathrm{E}}$ and $\% \mathrm{~Pb}_{\mathrm{E}}$ were $-0.45(P=0.005)$ and $-0.47(P=0.003)$ for $\mathrm{Cd}$ and $\mathrm{Pb}$ respectively. Large soil $\mathrm{P}$ concentrations may promote the precipitation of $\mathrm{Cd}$ and $\mathrm{Pb}$ as insoluble P compounds in soil (Atkinson et al., 2011; Fang et al., 2016; Garforth et al., 2016; McBride, 2016; Paltseva et al., 2018). It is worth noting, however, particularly in the case of $\% \mathrm{Cd}_{E}$, that there was an initial increase in metal lability with $\mathrm{P}_{\text {Total, }}$, followed by a downward trend. This may indicate that initially biosolids application has mobilising effects through increased organic matter, dissolved organic matter and the progressive occupancy of weaker metal adsorption sites with metal loading. This trend is then reversed when the immobilizing effect of phosphate becomes the predominant factor, for $\mathrm{Cd}$ and $\mathrm{Pb}$. 
294 Soluble metal concentrations $\left(\mathrm{M}_{\text {Soln }}\right)$ in soil were estimated by equilibration with $0.01 \mathrm{M}$

$295 \mathrm{Ca}\left(\mathrm{NO}_{3}\right)_{2}$; results are reported as supplementary material (Table S4). Values of $\mathrm{M}_{\text {Soln }}$ were less

296 than $1 \%$ of $\mathrm{M}_{\text {Total }}$ for most elements; mean values were $0.78 \%, 0.25 \%, 0.13 \%, 0.31 \%$ and

$2970.001 \%$ for $\mathrm{Ni}, \mathrm{Cu}, \mathrm{Zn}, \mathrm{Cd}$, and $\mathrm{Pb}$ respectively. Distribution coefficients $\left(\mathrm{K}_{\mathrm{d}}\right)$ were calculated

298 for each element as the ratio between the adsorbed isotopically exchangeable form $\left(\mathrm{M}_{E}-\mathrm{M}_{\text {soln; }}\right.$;

$\left.299 \mathrm{mg} \mathrm{kg}^{-1}\right)$ and the free ion activity $\left(\mathrm{M}^{2+} ; \mathrm{mg} \mathrm{L}^{-1}\right)$ in soil solution, determined from $\mathrm{M}_{\text {Soln }}$ in 0.01

$300 \mathrm{M} \mathrm{Ca}\left(\mathrm{NO}_{3}\right)_{2}$ following speciation using the geochemical model WHAM VII. Values of

$301 \log _{10}\left(\mathrm{~K}_{\mathrm{d}}\right)$ for $\mathrm{Ni}, \mathrm{Zn}$ and Cd were strongly correlated ( $r=0.79,0.93$, and 0.79 respectively)

302 with soil $\mathrm{pH}$, while no distinctive trend was observed for $\mathrm{Cu}$ and $\mathrm{Pb}(r=0.43$ and 0.44

303 respectively).

304 To relate metal partitioning between soil solid and solution phases to the variations in soil

305 properties, multiple regression analysis was used. The regression models were based on Sauvé

306 et al., (2000) where $\mathrm{M}_{\text {Total, }}$ LOI and soil $\mathrm{pH}$ were considered as major explanatory variables

307 controlling $\mathrm{K}_{\mathrm{d}}$. Concentrations of total soil metal $\left(\mathrm{M}_{\text {Total }}\right)$ were excluded from the regression

308 analysis because of the strong correlation between $\mathrm{M}_{\text {Total }}, \mathrm{M}_{E}$, and LOI indicating that they

309 provide redundant information which was confirmed by high variance inflation factors (VIF >

310 10). The results of the regression models are reported in Table 4. Most of the variation in $K_{d}$

311 for $\mathrm{Ni}, \mathrm{Zn}$, and $\mathrm{Cd}$ was described by the model (Table 4 ). However, only $25 \%$ and $22 \%$ of the

312 variation in $\mathrm{K}_{\mathrm{d}}$ were explained for $\mathrm{Cu}$ and $\mathrm{Pb}$, respectively, indicating that other soil factors

313 control the partitioning of these two metals. As expected, $\mathrm{pH}$ had positive coefficients in the

314 regression models reflecting the dual role of $\mathrm{pH}$ in controlling metal solubility through

315 increasing proton competition for binding sites and decreasing $\mathrm{pH}$-dependent surface charges

316 with decreasing pH (Sauvé et al., 2003; Shaheen et al., 2013). Most of the variation in $\mathrm{K}_{\mathrm{d}}$ for

$317 \mathrm{Ni}, \mathrm{Zn}$, and $\mathrm{Cd}$ was explained by soil $\mathrm{pH}$ only in the regression equations (Table 4). 
318 Surprisingly, the variation in $\mathrm{K}_{\mathrm{d}}$ explained by LOI was minor but this may have arisen because

319 LOI was negatively correlated with $\mathrm{pH}$ which may mask any independent effect of LOI on $\mathrm{K}_{\mathrm{d}}$.

320 Inclusion of other soil properties in the regression model was also explored. Only total Mn

321 concentration in soil was significant in the case of $\mathrm{Ni}, \mathrm{Zn}, \mathrm{Cd}$, and $\mathrm{Pb}$; including it in the 322 regression model increased the variation in $\mathrm{K}_{\mathrm{d}}$ values explained to $65 \%, 92 \%, 85 \%$, and $57 \%$

323 for $\mathrm{Ni}, \mathrm{Zn}, \mathrm{Cd}$, and $\mathrm{Pb}$ respectively.

\section{3.5.1. Metal speciation in solution.}

325 Metal speciation in the solution phase of the $0.01 \mathrm{M} \mathrm{Ca}\left(\mathrm{NO}_{3}\right)_{2}$ suspensions was calculated using WHAM VII. Cadmium, Ni, and Zn were largely ( $>91 \%$ on average) present as free ionic species, with minor proportions $(<10 \%)$ bound to DOC. Similarly, Ivezić et al., (2012) reported that only $9 \%$ and $7 \%$ of $\mathrm{Cd}$ and $\mathrm{Zn}$, respectively, were associated with $\mathrm{FA}$ in the soil solution and Zhang et al., (2015) found that including DOC as a factor did not improve the prediction of dissolved Ni using WHAM. By contrast, on average, $41 \%$ and $58 \%$ of dissolved $\mathrm{Pb}$ and $\mathrm{Cu}$ were complexed with DOC, respectively, reflecting their high affinity for soil organic matter. Again, this in agreement with Ivezić et al., (2012) who reported that $66 \%$ of $\mathrm{Cu}$ and $\mathrm{Pb}$ were bound to FA in the soil solution.

334 It has been well established that metal 'intensity', rather than 'quantity', is the most relevant representation of metal bioavailability in assessing the ecological consequence of metals in soil

336 (Golui et al., 2020; Hamels et al., 2014; McBride and Cai, 2015; Mossa et al., 2020). Using total metal concentration in soil overestimates the 'quantity' of available metal as only a portion of that is reactive. It is therefore important to use the reactive (labile) portion of soil metal as input for WHAM in order to estimate the free ion activity. Thus it is evident from Fig. 4 that using total metal concentrations as input to WHAM largely overestimated the free ion activities determined from solution data alone. Conversely, using the reactive metal concentrations (E- 
342 values) substantially improved the prediction of the free ion activity, particularly for Ni and

$343 \mathrm{Zn}$. The only exception was for $\mathrm{Pb}$ where no reasonable predictions were obtained irrespective

344 of which pool was used as input. This is consistent with the findings of several other authors

345 who reported poor predictions of Pb using WHAM (Bonten et al., 2008; Marzouk et al., 2013b;

346 Rennert et al., 2017). The poor prediction of the free ion activity of $\mathrm{Pb}$ could be due to the

347 formation of ternary complexes and poorly insoluble compounds with P (Marzouk et al., 348 2013b). It is clear from Fig. 4 that reasonable prediction can be obtained using only E-values 349 and selected characteristics of the solid phase in soil.

\subsection{Lead isotope ratios}

351 To assess the contribution of $\mathrm{Pb}$ sources to plant uptake, $\mathrm{Pb}$ isotope ratios in soil and the maize crop were determined. Two dominant $\mathrm{Pb}$ sources in the UK were used as end members in a simple binary mixing model: (i) $\mathrm{Pb}$ from leaded petrol with isotope ratios ${ }^{206} \mathrm{~Pb} /{ }^{207} \mathrm{~Pb}$ and ${ }^{208} \mathrm{~Pb} /{ }^{207} \mathrm{~Pb}$ estimated as $1.067 \pm 0.007$ and $2.340 \pm 0.011$ respectively (Sugden et al., 1993); and (ii) $\mathrm{Pb}$ ore from the Southern Pennine ore-field (U.K.) with values of ${ }^{206} \mathrm{~Pb} /{ }^{207} \mathrm{~Pb}$ and ${ }^{208} \mathrm{~Pb} /{ }^{207} \mathrm{~Pb}$ of $1.182 \pm 0.004$ and $2.458 \pm 0.002$ respectively (Rohl, 1996). The relative contribution of petrol-derived $\mathrm{Pb}$ to the total soil and plant $\mathrm{Pb}$ concentrations $\left(\% \mathrm{~Pb} b_{\mathrm{Petrol}}\right)$ was estimated using Eq. 3 (Farmer et al., 2005).

$$
\% P b_{\text {Petrol }}=100\left(\frac{I R_{\text {Ore }}-I R_{\text {Sample }}}{I R_{\text {Ore }}-I R_{\text {Petrol }}}\right)
$$

360 The IR indicates the isotopic ratio $\left({ }^{206} \mathrm{~Pb} /{ }^{207} \mathrm{~Pb}\right)$ and subscripts indicate the medium (Ore,

361 Petrol, Sample). Soil and plant samples had a range of isotope ratios extending between the two end members (Pennine $\mathrm{Pb}$ and petrol) (Fig. 5A). Soils with low $\mathrm{Pb}$ concentrations (i.e. low biosolids inputs) showed a greater influence from local ore or coal, whereas the contribution

364 from petrol-derived $\mathrm{Pb}$ was more apparent in the soils with high $\mathrm{Pb}$ content (Fig. 5B and $\mathrm{C}$ ).

365 The slope in Fig. 5C suggests that petrol-derived $\mathrm{Pb}$ constitutes about $52 \%$ of the $\mathrm{Pb}$ in 
biosolids on a time-averaged basis. The binary mixing model demonstrates a range of $\mathrm{Pb}$ sources in the maize crop; however, crucially, the plant samples showed a narrower range of $\mathrm{Pb}$ isotope ratios than the soil samples (Fig. 5A). Figure 5D compares petrol-derived $\mathrm{Pb}$ in soil with that in the maize crop. At high levels of petrol-derived $\mathrm{Pb}$ in soil, the isotopic signature of $\mathrm{Pb}$ in soil is similar to that in plant samples. However, the ratios are increasingly divergent at low proportions of petrol-derived $\mathrm{Pb}$ (i.e. high geogenic source). Two trends in Fig. 5D might suggest that the petrol-derived $\mathrm{Pb}$ is more accessible to plants than geogenic $\mathrm{Pb}$, possibly due to differences in contact time. This would be consistent with Izquierdo et al., (2012) who found that petrol- $\mathrm{Pb}$ was enriched in the bioavailable pools of $\mathrm{Pb}$ for alluvial soils within the same catchment as the current study. Alternatively, it is likely that most of the $\mathrm{Pb}$ measured in plant samples was the result of physical contamination from soil dust (despite sample washing). Thus, a small amount of dust from a neighbouring field with a large soil $\mathrm{Pb}$ concentration, and therefore a higher proportion of petrol-derived $\mathrm{Pb}$, will significantly affect the isotopic signature of plants growing on a soil with a low $\mathrm{Pb}$ concentration. The converse of course is not true - dust from a soil with low $\mathrm{Pb}$ concentration (i.e. mainly geogenic sources) will have a negligible effect on the isotopic signature of plants growing on a soil with a high $\mathrm{Pb}$ concentration. The net result is that, inevitably, the range of isotopic signatures in the plant samples is narrower than in the soils and shifted towards petrol-derived $\mathrm{Pb}$ (Fig. 5A).

\subsection{Plant uptake of metals}

Plant uptake of metals ( $\mathrm{Ni}, \mathrm{Cu}, \mathrm{Zn}, \mathrm{Cd}, \mathrm{Pb})$ was evaluated using different estimates of metal bioavailability in soil: $\mathrm{M}_{\text {Total }}, \mathrm{M}_{E}, \mathrm{M}_{\text {Soln }}$ and $\left(\mathrm{M}^{2+}\right)$ (Fig. 6 and Figs $\mathrm{S} 2$ - S5 in the supplementary material). All correlations were significant $(P<0.01)$ for the five trace metals and the four estimates of metal bioavailability explained more than $70 \%$ of the variation in $\mathrm{Ni}, \mathrm{Cu}, \mathrm{Zn}$ and Cd concentrations in the maize crop. For PbPlant (Fig. S5), only a maximum of $34 \%$ of the variation in $\mathrm{Pb}$ Plant concentration could be explained by $\mathrm{Pb}$ concentration in soil - probably due 
391 to surface contamination of plant samples by soil dust and very limited systemic uptake of $\mathrm{Pb}$

392 by the maize plants (Degryse et al., 2009; Nolan et al., 2005; Nordløkken et al., 2015). The

393 latter route is probably further limited by low Pb solubility (McBride et al., 2014; Schreck et

394 al., 2012), as is the case of the sludge-amended soils, due to high phosphate concentrations.

395 In general, soil total metal concentration is of little use of assessing metal bioavailability and 396 plant uptake (Ciadamidaro et al., 2017; McBride et al., 2009) whereas concentration or activity 397 in the soil solution, regarded as an 'intensity' factor, provide the best predictors for plant uptake 398 and toxicity (Black et al., 2011; Zhang et al., 2015). However, in the present study, as seen in 399 Fig. 6 (and Fig S2-S5), there was hardly any difference amongst the contrasting estimates of soil metal availability. This lack of discrimination is likely to arise where a single soil type is in receipt of variable amounts of a single contaminant source and is subject to a fairly uniform management regime. Thus, it is reasonable to assume that all the factors that are likely to affect metal availability in soils receiving biosolids $(\mathrm{pH}$, organic matter concentration, phosphate concentration, metal loading) will co-vary with sludge loading (Table S3). This coupled with the narrow $\mathrm{pH}$ range $(6-6.9)$ controlled by management may explain the similar ability of soil capacity variables (i.e. metal reservoir; $\left.\mathrm{M}_{\text {soil }}, \mathrm{M}_{E}\right)$ and intensity variables $\left(\mathrm{M}_{\text {soln }}, \mathrm{M}^{2+}\right)$ to predict

407 MPlant.

\section{Conclusions}

409 The consequences of long-term application of biosolids to arable soils on metal dynamics were 410 investigated. The study was based on a site that had been utilised for biosolids disposal to arable 411 land for well over a century. Several important conclusions emerged.

412 Despite the large concentration of metals, low levels of lability (\%) were observed for some metals $(19.9 \pm 10.7,36.0 \pm 5.16,21.5 \pm 7.59,28.0 \pm 4.21,5.19 \pm 2.56$ for $\mathrm{Ni}, \mathrm{Cu}$,

$414 \mathrm{Zn}, \mathrm{Cd}$, and $\mathrm{Pb}$ respectively). These observations support the 'protection hypotheses' 
regarding biosolids application to soil in which constituents of biosolids, such as organic

416 matter and phosphate, accumulate in the soil concurrently with metals and thereby reduce

417 metal reactivity. Thus, the potential risks arising from biosolids application for over 100

$418 \quad$ years may be low.

$419 \bigcirc$ Two distinct trends of metal lability with P concentration in soil were observed. The \% 420 lability of $\mathrm{Cd}$ and $\mathrm{Pb}$ declined as soil $\mathrm{P}$ concentration increased suggesting a direct 421 interaction. By contrast the lability of $\mathrm{Ni}, \mathrm{Zn}$, and $\mathrm{Cu}$ increased with soil $\mathrm{P}$. This may be 422 due to the strong correlation between $\mathrm{P}$ and total metal content and progressive occupancy 423 of weaker binding sites on soil humus and metal oxides as metal concentration increases.

424 Thus, there is a case for metal specific behaviour to be considered when devising 425 regulatory limits governing the use of biosolids in agriculture.

$426 \bigcirc$ Average mole ratios of $\mathrm{Zn}$ to $\mathrm{Ni}, \mathrm{Cu}, \mathrm{Cd}$ and $\mathrm{Pb}$ in soil were 4.4, 2.4, 69, and 8.4, reflecting 427 disposal through household sewage and industrial wastewater from the city of Nottingham.

$428 \bigcirc$ Analysis of the $\mathrm{Pb}$ isotopic composition in the maize crop revealed a greater proportion of 429 petrol-derived $\mathrm{Pb}$, compared to the underlying topsoil, at low crop $\mathrm{Pb}$ concentrations. This 430 may indicate the influence of soil dust originating from more highly contaminated nearby 431 fields. This was consistent with a relatively poor relationship between soil and plant $\mathrm{Pb}$ 432 concentrations compared to the other metals studied.

$433 \quad \mathrm{~T}$ The European Parliament (Directive 2002/32/EC, 2002) set limits of $\mathrm{As}, \mathrm{Cd}, \mathrm{Hg}$ and $\mathrm{Pb}$ in 434 animal feed of 2, 1, 0.1, and $30 \mathrm{mg} \mathrm{kg}^{-1}$ respectively. Cadmium exceeded these limits in 43515 fields, with mean and maximum Cd concentrations of 1.2 and $6.1 \mathrm{mg} \mathrm{kg}^{-1}$ respectively. 436 However, the maximum concentrations of $\mathrm{As}, \mathrm{Hg}$, and $\mathrm{Pb}$ were $0.35,0.06$, and 0.335 437 respectively - considerably below the EU limits of 2, 0.1, and 30 respectively despite high $438 \quad$ levels of enrichment in the soils on site. 
O High correlation between all measures of metal availability in soil in addition to the limited soil $\mathrm{pH}$ range obscured any advantage in using soluble or labile metal concentration over total soil metal concentration in predicting metal bioavailability, determined as

\section{ACKNOWLEDGMENTS}

444

445 concentration in a fodder maize crop.

This work was funded by Islamic Development Bank's Merit Scholarship Programme for High Technology awarded to AW Mossa (Reference No. 36/11204351, File No. 78/SYR/P31). The authors would like to thank Severn Trent Water Ltd. for their co-operation, and the anonymous reviewers for their constructive comments and suggestions.

\section{References:}

Anschutz, P., Zhong, S., Sundby, B., Mucci, A., Gobeil, C., 1998. Burial efficiency of phosphorus and the geochemistry of iron in continental margin sediments. Limnol. Oceanogr. 43, 53-64. https://doi.org/10.4319/lo.1998.43.1.0053

Antille, D.L., Godwin, R.J., Sakrabani, R., Seneweera, S., Tyrrel, S.F., Johnston, A.E., 2017. Field-Scale Evaluation of Biosolids-Derived Organomineral Fertilizers Applied to Winter Wheat in England. Agron. J. 0. https://doi.org/10.2134/agronj2016.09.0495

Atkinson, N.R., Bailey, E.H., Tye, A.M., Breward, N., Young, S.D., 2011. Fractionation of lead in soil by isotopic dilution and sequential extraction. Environ. Chem. 8, 493-500.

Bing, H., Wu, Y., Zhou, J., Li, R., Luo, J., Yu, D., 2016. Vegetation and Cold Trapping Modulating Elevation-dependent Distribution of Trace Metals in Soils of a High Mountain in Eastern Tibetan Plateau. Sci. Rep. 6, 24081. https://doi.org/10.1038/srep24081

Black, A., McLaren, R.G., Reichman, S.M., Speir, T.W., Condron, L.M., 2011. Evaluation of soil metal bioavailability estimates using two plant species (L.perenne and T. aestivum) grown in a range of agricultural soils treated with biosolids and metal salts. Environ. Pollut. 159, 1523-1535. https://doi.org/10.1016/j.envpol.2011.03.004

Bonten, L.T.C., Groenenberg, J.E., Weng, L., van Riemsdijk, W.H., 2008. Use of speciation and complexation models to estimate heavy metal sorption in soils. Geoderma 146, 303-310. https://doi.org/10.1016/j.geoderma.2008.06.005

British Geological Survey, 2006. Regional Geochemistry of Humber-Trent: Stream Water, Stream Sediment and Soil.

Buekers, J., Degryse, F., Maes, A., Smolders, E., 2008. Modelling the effects of ageing on Cd, $\mathrm{Zn}, \mathrm{Ni}$ and $\mathrm{Cu}$ solubility in soils using an assemblage model. Eur. J. Soil Sci. 59, 11601170. https://doi.org/10.1111/j.1365-2389.2008.01053.x

Ciadamidaro, L., Puschenreiter, M., Santner, J., Wenzel, W.W., Madejón, P., Madejón, E., 2017. Assessment of trace element phytoavailability in compost amended soils using different methodologies. J. Soils Sediments 17, 1251-1261. https://doi.org/10.1007/s11368-015-1283-3 
Degryse, F., Smolders, E., Zhang, H., Davison, W., 2009. Predicting availability of mineral elements to plants with the DGT technique: a review of experimental data and interpretation by modelling. Environ. Chem. 6, 198-218. https://doi.org/10.1071/EN09010

Directive 2002/32/EC, 2002. Directive 2002/32/EC of the European Parliament and of the Council of 7 May 2002 on undesirable substances in animal feed - Council statement.

Fang, W., Wei, Y., Liu, J., 2016. Comparative characterization of sewage sludge compost and soil: Heavy metal leaching characteristics. J. Hazard. Mater. 310, 1-10. https://doi.org/10.1016/j.jhazmat.2016.02.025

Farmer, J.G., Graham, M.C., Bacon, J.R., Dunn, S.M., Vinogradoff, S.I., MacKenzie, A.B., 2005. Isotopic characterisation of the historical lead deposition record at Glensaugh, an organic-rich, upland catchment in rural N.E. Scotland. Sci. Total Environ. 346, 121137. https://doi.org/10.1016/j.scitotenv.2004.11.020

Gäbler, H.-E., Bahr, A., Mieke, B., 1999. Determination of the interchangeable heavy-metal fraction in soils by isotope dilution mass spectrometry. Fresenius J. Anal. Chem. 365, 409-414. https://doi.org/10.1007/s002160051632

Garforth, J.M., Bailey, E.H., Tye, A.M., Young, S.D., Lofts, S., 2016. Using isotopic dilution to assess chemical extraction of labile $\mathrm{Ni}, \mathrm{Cu}, \mathrm{Zn}, \mathrm{Cd}$ and $\mathrm{Pb}$ in soils. Chemosphere 155, 534-541. https://doi.org/10.1016/j.chemosphere.2016.04.096

Golui, D., Datta, S.P., Dwivedi, B.S., Meena, M.C., Trivedi, V.K., 2020. Prediction of free metal ion activity in contaminated soils using WHAM VII, baker soil test and solubility model. Chemosphere 243, 125408. https://doi.org/10.1016/j.chemosphere.2019.125408

Groenenberg, J.E., Römkens, P.F.A.M., Zomeren, A.V., Rodrigues, S.M., Comans, R.N.J., 2017. Evaluation of the Single Dilute $(0.43 \mathrm{M})$ Nitric Acid Extraction to Determine Geochemically Reactive Elements in Soil. Environ. Sci. Technol. 51, 2246-2253. https://doi.org/10.1021/acs.est.6b05151

Hamels, F., Malevé, J., Sonnet, P., Kleja, D.B., Smolders, E., 2014. Phytotoxicity of trace metals in spiked and field-contaminated soils: Linking soil-extractable metals with toxicity. Environ. Toxicol. Chem. 33, 2479-2487. https://doi.org/10.1002/etc.2693

Hamon, R.E., Parker, D.R., Lombi, E., 2008. Advances in Isotopic Dilution Techniques in Trace Element Research: A Review of Methodologies, Benefits, and Limitations, in: Advances in Agronomy. Academic Press, pp. 289-343. https://doi.org/10.1016/S00652113(08)00406-9

Hernandez-Soriano, M.C., Jimenez-Lopez, J.C., 2012. Effects of soil water content and organic matter addition on the speciation and bioavailability of heavy metals. Sci. Total Environ. 423, 55-61. https://doi.org/10.1016/j.scitotenv.2012.02.033

Hooda, P.S., 2010. Assessing Bioavailability of Soil Trace Elements, in: Trace Elements in Soils. Wiley, Chichester, West Sussex.

Ivezić, V., Almås, Å.R., Singh, B.R., 2012. Predicting the solubility of $\mathrm{Cd}, \mathrm{Cu}, \mathrm{Pb}$ and $\mathrm{Zn}$ in uncontaminated Croatian soils under different land uses by applying established regression models. Geoderma 170, 89-95. https://doi.org/10.1016/j.geoderma.2011.11.024

Izquierdo, M., M. Tye, A., R. Chenery, S., 2013. Lability, solubility and speciation of $\mathrm{Cd}, \mathrm{Pb}$ and $\mathrm{Zn}$ in alluvial soils of the River Trent catchment UK. Environ. Sci. Process. Impacts 15, 1844-1858. https://doi.org/10.1039/C3EM00370A

Izquierdo, M., Tye, A.M., Chenery, S.R., 2012. Sources, lability and solubility of $\mathrm{Pb}$ in alluvial soils of the River Trent catchment, U.K. Sci. Total Environ. 433, 110-122. https://doi.org/10.1016/j.scitotenv.2012.06.039 
Kabata-Pendias, A., Pendias, H., 2001. Trace elements in soils and plants, 3rd ed. ed. CRC Press, Boca Raton, Fla.

Kim, R.-Y., Yoon, J.-K., Kim, T.-S., Yang, J.E., Owens, G., Kim, K.-R., 2015. Bioavailability of heavy metals in soils: definitions and practical implementation-a critical review. Environ. Geochem. Health 37, 1041-1061. https://doi.org/10.1007/s10653-015-9695$\mathrm{y}$

Lofts, S., Tipping, E., Hamilton-Taylor, J., 2008. The Chemical Speciation of Fe(III) in Freshwaters. Aquat. Geochem. 14, 337-358. https://doi.org/10.1007/s10498-0089040-5

Mamindy-Pajany, Y., Sayen, S., Mosselmans, J.F.W., Guillon, E., 2014. Copper, Nickel and Zinc Speciation in a Biosolid-Amended Soil: $\mathrm{pH}$ Adsorption Edge, $\mu$-XRF and $\mu-$ XANES Investigations. Environ. Sci. Technol. 48, 7237-7244. https://doi.org/10.1021/es5005522

Marzouk, E.R., Chenery, S.R., Young, S.D., 2013a. Measuring reactive metal in soil: a comparison of multi-element isotopic dilution and chemical extraction. Eur. J. Soil Sci. 64, 526-536. https://doi.org/10.1111/ejss.12043

Marzouk, E.R., Chenery, S.R., Young, S.D., 2013b. Predicting the solubility and lability of Zn, $\mathrm{Cd}$, and $\mathrm{Pb}$ in soils from a minespoil-contaminated catchment by stable isotopic exchange. Geochim. Cosmochim. Acta 123, 1-16. https://doi.org/10.1016/j.gca.2013.09.004

McBride, M.B., 2016. Extractability of $\mathrm{Pb}$ in urban gardens and orchards linked to soil properties. Eur. J. Soil Sci. 67, 686-694. https://doi.org/10.1111/ejss.12372

McBride, M.B., Cai, M., 2015. Copper and zinc aging in soils for a decade: changes in metal extractability and phytotoxicity. Environ. Chem. 13, 160-167. https://doi.org/10.1071/EN15057

McBride, M.B., Pitiranggon, M., Kim, B., 2009. A COMPARISON OF TESTS FOR EXTRACTABLE COPPER AND ZINC IN METAL-SPIKED AND FIELDCONTAMINATED $\quad$ SOIL: Soil Sci. $\quad$ 174, 439-444. https://doi.org/10.1097/SS.0b013e3181b66856

McBride, M.B., Shayler, H.A., Spliethoff, H.M., Mitchell, R.G., Marquez-Bravo, L.G., Ferenz, G.S., Russell-Anelli, J.M., Casey, L., Bachman, S., 2014. Concentrations of lead, cadmium and barium in urban garden-grown vegetables: The impact of soil variables. Environ. Pollut. 194, 254-261. https://doi.org/10.1016/j.envpol.2014.07.036

Meers, E., Du Laing, G., Unamuno, V., Ruttens, A., Vangronsveld, J., Tack, F.M.G., Verloo, M.G., 2007. Comparison of cadmium extractability from soils by commonly used single extraction protocols. Geoderma 141, 247-259. https://doi.org/10.1016/j.geoderma.2007.06.002

Mossa, A.-W., Dickinson, M.J., West, H.M., Young, S.D., Crout, N.M.J., 2017. The response of soil microbial diversity and abundance to long-term application of biosolids. Environ. Pollut. 224, 16-25. https://doi.org/10.1016/j.envpol.2017.02.056

Mossa, A.-W., Young, S.D., Crout, N.M.J., 2020. Zinc uptake and phyto-toxicity: Comparing intensity- and capacity-based drivers. Sci. Total Environ. 699, 134314. https://doi.org/10.1016/j.scitotenv.2019.134314

Murphy, J., Riley, J.P., 1962. A modified single solution method for the determination of phosphate in natural waters. Anal. Chim. Acta 27, 31-36. https://doi.org/10.1016/S0003-2670(00)88444-5

Nolan, A.L., Zhang, H., McLaughlin, M.J., 2005. Prediction of Zinc, Cadmium, Lead, and Copper Availability to Wheat in Contaminated Soils Using Chemical Speciation, Diffusive Gradients in Thin Films, Extraction, and Isotopic Dilution Techniques. J. Environ. Qual. 34, 496-507. https://doi.org/10.2134/jeq2005.0496 
601

602

603

604

605

606

607

608

609

610

611

612

613

614

615

616

617

618

619

620

621

622

623

624

Nordløkken, M., Berg, T., Flaten, T.P., Steinnes, E., 2015. Essential and non-essential elements in natural vegetation in southern Norway: Contribution from different sources. Sci. Total Environ. 502, 391-399. https://doi.org/10.1016/j.scitotenv.2014.09.038

Olsen, S.R., Cole, C.V., Watanabe, F.S., Dean, L.A., 1954. Estimation of available phosphorus in soils by extraction with sodium bicarbonate. US Dep. Agric. Circular, Vol 939, (P. 19).

Paltseva, A., Cheng, Z., Deeb, M., Groffman, P.M., Maddaloni, M., 2018. Variability of Bioaccessible Lead in Urban Garden Soils. Soil Sci. Publish Ahead of Print. https://doi.org/10.1097/SS.0000000000000232

$\mathrm{R}$ Core Team, 2018. A language and environment for statistical computing. R Foundation for Statistical Computing, Vienna, Austria. URL https://www.R-project.org/.

Rennert, T., Rabus, W., Rinklebe, J., 2017. Modelling the concentrations of dissolved contaminants $(\mathrm{Cd}, \mathrm{Cu}, \mathrm{Ni}, \mathrm{Pb}, \mathrm{Zn})$ in floodplain soils. Environ. Geochem. Health 39, 331-344. https://doi.org/10.1007/s10653-016-9859-4

Rohl, B.M., 1996. Lead Isotope Data from the Isotrace Laboratory, Oxford: Archaeometry Data Base 2, Galena from Britain and Ireland. Archaeometry 38, 165-180. https://doi.org/10.1111/j.1475-4754.1996.tb00769.x

Roig, N., Sierra, J., Martí, E., Nadal, M., Schuhmacher, M., Domingo, J.L., 2012. Long-term amendment of Spanish soils with sewage sludge: Effects on soil functioning. Agric. Ecosyst. Environ. 158, 41-48. https://doi.org/10.1016/j.agee.2012.05.016

Rosenfeld, C.E., Chaney, R.L., Martínez, C.E., 2018. Soil geochemical factors regulate Cd accumulation by metal hyperaccumulating Noccaea caerulescens (J. Presl \& C. Presl) F.K. Mey in field-contaminated soils. Sci. Total Environ. 616-617, 279-287. https://doi.org/10.1016/j.scitotenv.2017.11.016

Samaras, V., Tsadilas, C.D., Stamatiadis, S., 2008. Effects of Repeated Application of Municipal Sewage Sludge on Soil Fertility, Cotton Yield, and Nitrate Leaching. Agron. J. 100, 477-483. https://doi.org/10.2134/agronj2007.0162

Sauvé, S., Hendershot, W., Allen, H.E., 2000. Solid-Solution Partitioning of Metals in Contaminated Soils: Dependence on $\mathrm{pH}$, Total Metal Burden, and Organic Matter. Environ. Sci. Technol. 34, 1125-1131. https://doi.org/10.1021/es9907764

Sauvé, S., Manna, S., Turmel, M.-C., Roy, A.G., Courchesne, F., 2003. Solid-Solution Partitioning of $\mathrm{Cd}, \mathrm{Cu}, \mathrm{Ni}, \mathrm{Pb}$, and $\mathrm{Zn}$ in the Organic Horizons of a Forest Soil. Environ. Sci. Technol. 37, 5191-5196. https://doi.org/10.1021/es030059g

Schreck, E., Foucault, Y., Sarret, G., Sobanska, S., Cécillon, L., Castrec-Rouelle, M., Uzu, G., Dumat, C., 2012. Metal and metalloid foliar uptake by various plant species exposed to atmospheric industrial fallout: Mechanisms involved for lead. Sci. Total Environ. 427428, 253-262. https://doi.org/10.1016/j.scitotenv.2012.03.051

Shaheen, S.M., Tsadilas, C.D., Rinklebe, J., 2013. A review of the distribution coefficients of trace elements in soils: Influence of sorption system, element characteristics, and soil colloidal properties. Adv. Colloid Interface Sci. 201-202, 43-56. https://doi.org/10.1016/j.cis.2013.10.005

Singh, R.P., Agrawal, M., 2008. Potential benefits and risks of land application of sewage sludge. Waste Manag. 28, 347-358. https://doi.org/10.1016/j.wasman.2006.12.010

Stacey, S., Merrington, G., McLaughlin, M.J., 2001. The effect of aging biosolids on the availability of cadmium and zinc in soil. Eur. J. Soil Sci. 52, 313-321. https://doi.org/10.1046/j.1365-2389.2001.00376.x

Stietiya, M.H., Wang, J.J., 2011. Effect of Organic Matter Oxidation on the Fractionation of Copper, Zinc, Lead, and Arsenic in Sewage Sludge and Amended Soils. J. Environ. Qual. 40, 1162-1171. https://doi.org/10.2134/jeq2011.0008 
640

641

642

643

644

645

646

647

648

649

650

651

652

653

654

655

656
Sugden, C.L., Farmer, J.G., MacKenzie, A.B., 1993. Isotopic ratios of lead in contemporary environmental material from Scotland. Environ. Geochem. Health 15, 59-65. https://doi.org/10.1007/BF02627823

Sutherland, R.A., 2000. Bed sediment-associated trace metals in an urban stream, Oahu, Hawaii. Environ. Geol. 39, 611-627. https://doi.org/10.1007/s002540050473

The Sludge Use in Agriculture Regulations, 1989. The Sludge Use in Agriculture Regulations [WWW

Document].

URL http://www.legislation.gov.uk/uksi/1989/1263/contents/made (accessed 1.7.19).

Tipping, E., 1994. WHAMC-A chemical equilibrium model and computer code for waters, sediments, and soils incorporating a discrete site/electrostatic model of ion-binding by humic substances. Comput. Geosci. 20, 973-1023. https://doi.org/10.1016/00983004(94)90038-8

Tye, A.M., Young, S.D., Crout, N.M.J., Zhang, H., Preston, S., Barbosa-Jefferson, V.L., Davison, W., McGrath, S.P., Paton, G.I., Kilham, K., Resende, L., 2003. Predicting the activity of $\mathrm{Cd} 2+$ and $\mathrm{Zn} 2+$ in soil pore water from the radio-labile metal fraction. Geochim. Cosmochim. Acta 67, 375-385. https://doi.org/10.1016/S00167037(02)01138-9

Usman, A., Louise Ander, E., H. Bailey, E., Nelms, S., Pashley, V., D. Young, S., R. Chenery, S., 2018. Optimisation of a current generation ICP-QMS and benchmarking against MC-ICP-MS spectrometry for the determination of lead isotope ratios in environmental samples. J. Anal. At. Spectrom. 33, 2184-2194. https://doi.org/10.1039/C8JA00290H

Wang, X., Chen, T., Ge, Y., Jia, Y., 2008. Studies on land application of sewage sludge and its limiting factors. J. Hazard. Mater. 160, 554-558. https://doi.org/10.1016/j.jhazmat.2008.03.046

Young, S.D., Zhang, H., Tye, A.M., Maxted, A., Thums, C., Thornton, I., 2005. Characterizing the availability of metals in contaminated soils. I. The solid phase: sequential extraction and isotopic dilution. Soil Use Manag. 21, 450-458. https://doi.org/10.1079/SUM2005348

Zhang, X., Li, J., Wei, D., Li, B., Ma, Y., 2015. Predicting Soluble Nickel in Soils Using Soil Properties and Total Nickel. PLOS ONE 10, e0133920. https://doi.org/10.1371/journal.pone.0133920 
Table captions

Table 1. Soil organic matter (LOI), $\mathrm{pH}$ and elemental concentrations $\left(\mathrm{mg} \mathrm{kg}^{-1}\right)$ in soil

Table 2. Estimates of average $(n=38)$ annual metal loss through leaching and offtake by crop. Numbers between brackets denote standard deviations

Table 3. $E$-values $\left(\mathrm{mg} \mathrm{kg}^{-1}\right)$ and 'lability' (E-value as a \% of $\left.\mathrm{M}_{\text {Total }}\right)$

Table 4. Coefficients of the multiple regression equation used for predicting distribution coefficient $\mathrm{K}_{\mathrm{d}}$. Superscripts 'NS' indicate that the coefficient was not significant $(\mathrm{P}<0.05)$. 
Table 1. Soil organic matter (LOI), $\mathrm{pH}$ and elemental concentration $\left(\mathrm{mg} \mathrm{kg}^{-1}\right)$ in soil

\begin{tabular}{ccccc}
\hline & Mean & Minimum & Maximum & Std. deviation \\
\hline $\mathrm{pH}$ & 6.38 & 5.95 & 6.94 & 0.35 \\
$\mathrm{LOI}(\%)$ & 10.2 & 3.52 & 23.4 & 4.96 \\
\hline \multicolumn{5}{c}{$\left(\mathrm{mg} \mathrm{kg}^{-1}\right)$} \\
$\mathrm{P}$ & 4750 & 945 & 13700 & 3230 \\
$\mathrm{Ni}$ & 114 & 24.4 & 415 & 107 \\
$\mathrm{Cu}$ & 198 & 25.3 & 766 & 211 \\
$\mathrm{Zn}$ & 565 & 122 & 2050 & 532 \\
$\mathrm{Cd}$ & 9.89 & 0.43 & 48.6 & 12.7 \\
$\mathrm{~Pb}$ & 246 & 68.6 & 688 & 194 \\
\hline
\end{tabular}


Table 2. Estimates of average $(n=38)$ annual metal loss through leaching and offtake by plant. Numbers between brackets denote standard deviations

\begin{tabular}{cccccc}
\hline LOSS (\%) & $\mathrm{Cr}$ & $\mathrm{Cu}$ & $\mathrm{Zn}$ & $\mathrm{Cd}$ & $\mathrm{Rb}$ \\
\hline \multirow{2}{*}{ Plant offtake } & $\begin{array}{c}0.00156 \\
( \pm 0.00444)\end{array}$ & $\begin{array}{c}0.0221 \\
( \pm 0.0144)\end{array}$ & $\begin{array}{c}0.0727 \\
( \pm 0.0278)\end{array}$ & $\begin{array}{c}0.0570 \\
( \pm 0.0318)\end{array}$ & $\begin{array}{c}0.0406 \\
( \pm 0.0332)\end{array}$ \\
\hline \multirow{2}{*}{ Leaching } & $\begin{array}{c}0.00159 \\
( \pm 0.000686)\end{array}$ & $\begin{array}{c}0.0343 \\
( \pm 0.00858)\end{array}$ & $\begin{array}{c}0.0178 \\
( \pm 0.0142)\end{array}$ & $\begin{array}{c}0.0424 \\
( \pm 0.0184)\end{array}$ & $\begin{array}{c}0.00464 \\
( \pm 0.00416)\end{array}$ \\
\hline
\end{tabular}


Table 3. $E$-values $\left(\mathrm{mg} \mathrm{kg}^{-1}\right)$ and 'lability' (E-value as a \% of $\left.\mathrm{M}_{\text {Total }}\right)$

\begin{tabular}{c|cccc|cccc}
\hline & \multicolumn{4}{|c|}{$E$-values $\left(\mathrm{mg} \mathrm{kg}^{-1}\right)$} & \multicolumn{5}{c}{ Lability $\left(\% \mathrm{M}_{E}\right)$} \\
\cline { 2 - 9 } & Mean & Median & Min & Max & Mean & Median & Min & Max \\
\hline $\mathrm{Ni}$ & 32.1 & 17.3 & 1.1 & 176 & 19.9 & 18.8 & 3.30 & 42.4 \\
$\mathrm{Cu}$ & 76.5 & 45.3 & 5.8 & 304 & 36.0 & 37.0 & 22.9 & 44.2 \\
$\mathrm{Zn}$ & 149 & 81.1 & 12.0 & 679 & 21.5 & 22.1 & 7.6 & 33.2 \\
$\mathrm{Cd}$ & 2.5 & 1.5 & 0.1 & 11.3 & 28.0 & 28.3 & 19.7 & 37.3 \\
$\mathrm{~Pb}$ & 10.9 & 9.4 & 1.3 & 36.4 & 5.30 & 4.80 & 1.50 & 12.6 \\
\hline
\end{tabular}


Table 4. Coefficients of the multiple regression equation used for predicting distribution coefficient $\mathrm{K}_{\mathrm{d}}$. Superscripts 'NS' indicate that the coefficient was not significant $(\mathrm{P}<0.05)$

\begin{tabular}{|c|c|c|c|c|c|c|c|}
\hline & \multicolumn{3}{|c|}{ Regression equation } & \multirow[b]{2}{*}{$\mathrm{R}^{2}$} & \multicolumn{3}{|c|}{ Variance explained (\%) } \\
\hline & Intercept & $\mathrm{pH}$ & LOI & & $\mathrm{pH}$ & LOI & Residual \\
\hline $\mathrm{Ni}$ & $-1.53^{\mathrm{NS}}$ & 0.70 & $-0.09^{\mathrm{NS}}$ & 0.62 & 61.7 & 0.38 & 37.9 \\
\hline $\mathrm{Cu}$ & $-1.24^{\mathrm{NS}}$ & 0.89 & $0.67^{\mathrm{NS}}$ & 0.25 & 18.4 & 7.12 & 74.5 \\
\hline $\mathrm{Zn}$ & -4.73 & 12.8 & 0.27 & 0.88 & 86.5 & 1.84 & 11.5 \\
\hline $\mathrm{Cd}$ & -1.36 & 0.67 & 0.4 & 0.76 & 62.2 & 13.5 & 24.3 \\
\hline $\mathrm{Pb}$ & 3.57 & 0.43 & -0.30 & 0.22 & 19.2 & 2.57 & 78.2 \\
\hline
\end{tabular}




\section{Figure captions}

Figure 1. Box and whisker diagram of total elemental concentrations in topsoil from 38 arable field locations at a dedicated sewage sludge processing facility.

Figure 2. Ratios of $\mathrm{Zn}$ to $\mathrm{Rb}, \mathrm{Cr}, \mathrm{Cu}$ and $\mathrm{Cd}$ as a function of total $\mathrm{P}$ concentration in soil.

Figure 3. Variation in $\% \mathrm{M}_{E}$ with $\mathrm{P}_{\text {Total }}$ for $\mathrm{Ni}, \mathrm{Cu}, \mathrm{Zn}, \mathrm{Cd}$ and $\mathrm{Pb}$.

Figure 4. Comparison between free ion activities calculated by WHAM using only solution data (X-axis) and the free ion activities (Y-axis) calculated using either total metal concentration in soil (diamond; $\bullet$ ) or E-values (circle; •) as WHAM inputs. The solid line represents the 1:1 relationship.

Figure 5. (A) Lead isotope signatures in soil and plant samples. Petrol- $\mathrm{Pb}$ and geogenic- $\mathrm{Pb}$ signatures are shown as end members; the dashed line is the mixing line between them; (B) ${ }^{206} \mathrm{~Pb} /{ }^{207} \mathrm{~Pb}$ plotted against soil total metal content; (C) the relationship between petrol-derived $\mathrm{Pb}$ and $\mathrm{Pb}_{\text {Total }}$; (D) \% $\mathrm{Pb}$ Petrol in soil and the maize crop. Symbol size in $\mathrm{B}$ and $\mathrm{D}$ is proportional to total $\mathrm{Pb}$ concentration in soil.

Figure 6. Relationships between Cd concentrations in the maize crop and soil. Potential drivers for Cd uptake included (A) $\mathrm{Cd}_{\text {Total }}$, (B) $\mathrm{Cd}_{E},(\mathrm{C}) \mathrm{Cd}_{\text {soln }}$, (D) $\mathrm{Cd}^{2+}$ ion activity. The solid lines represent a linear regression fit; the grey shaded areas represent $95 \%$ confidence interval around fitted values. 
Figure 1

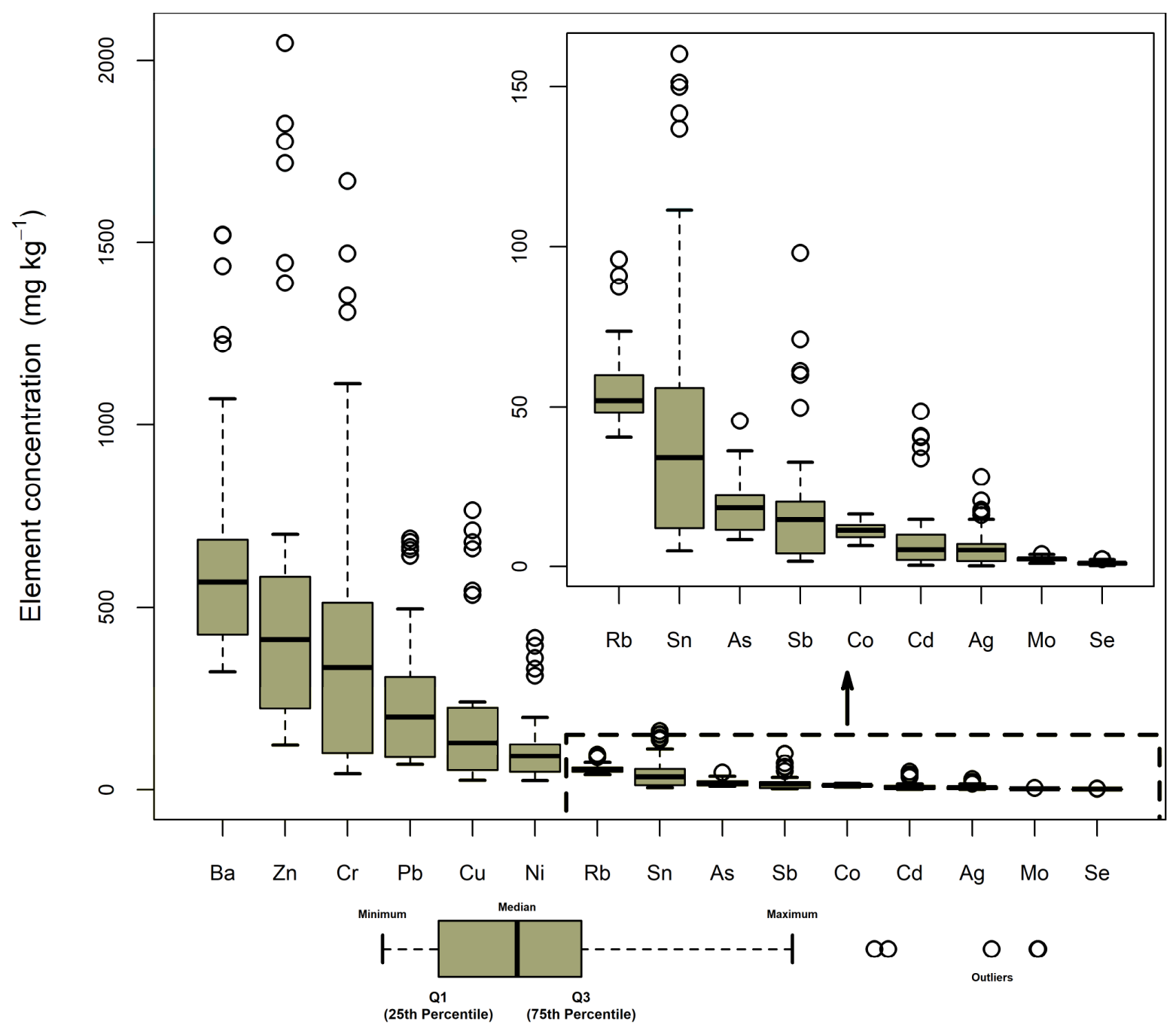


Figure 2
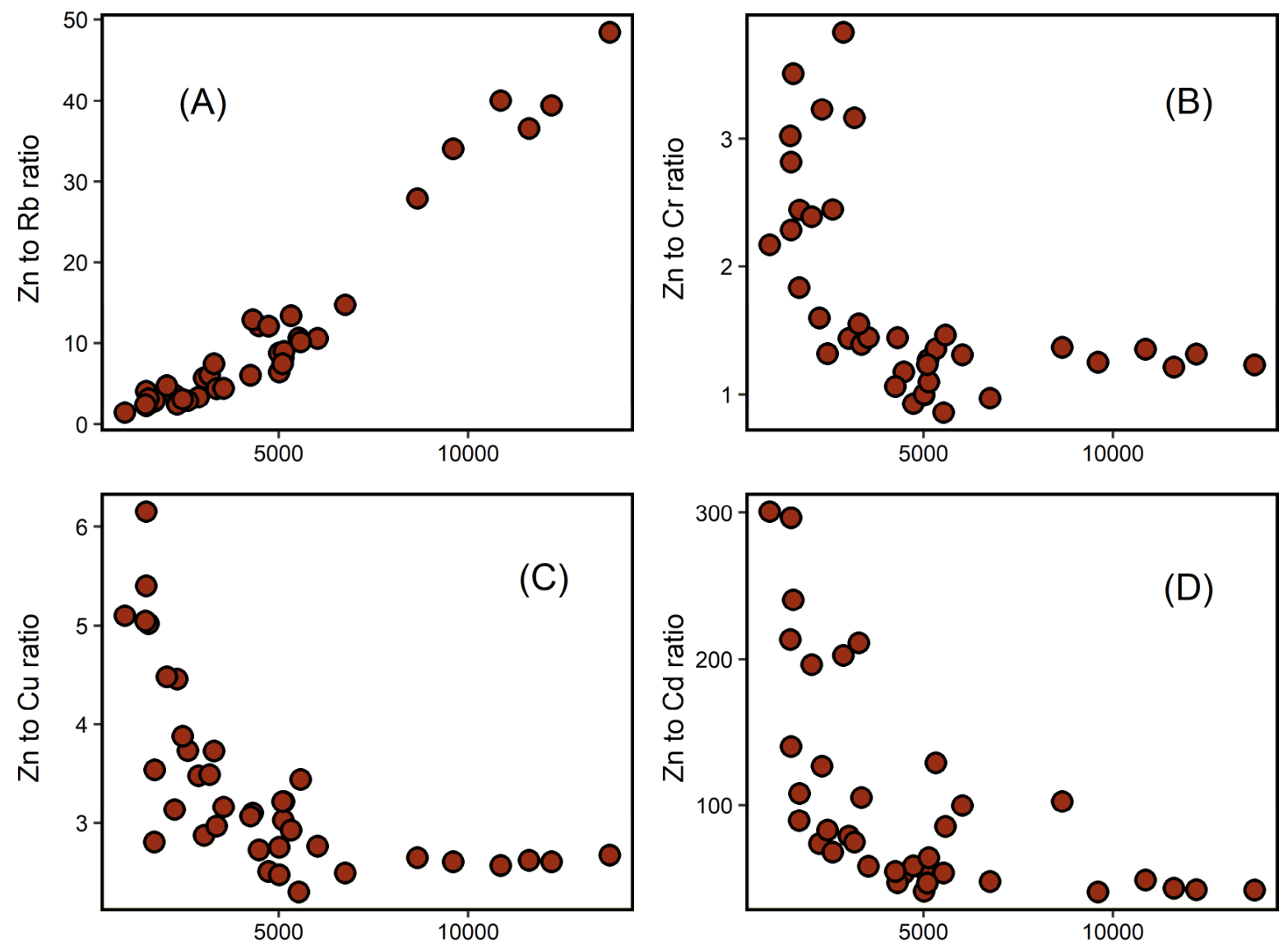

Total $\mathrm{P}$ in soil $\left(\mathrm{mg} \mathrm{kg}^{-1}\right)$ 
Figure 3

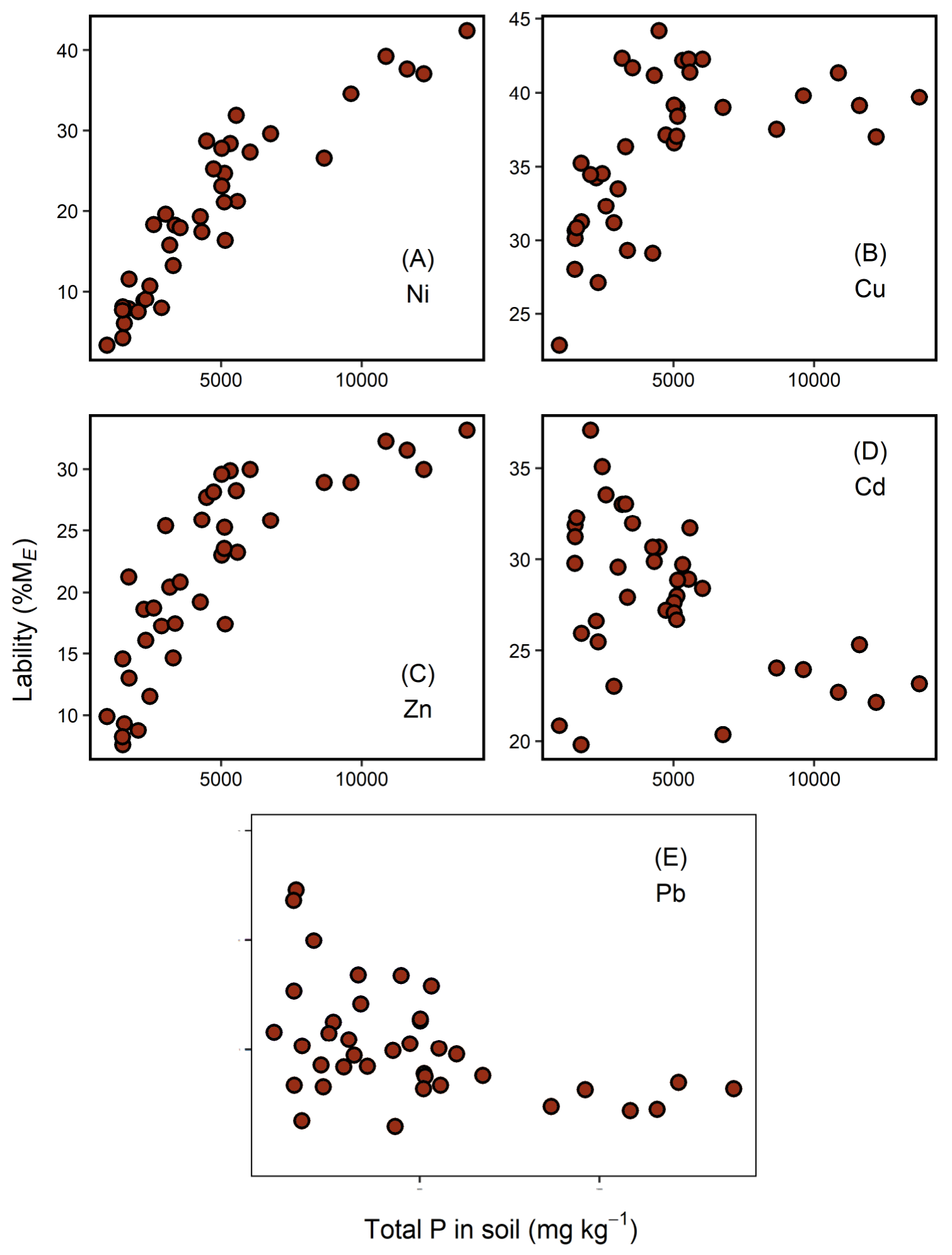


Fig 4
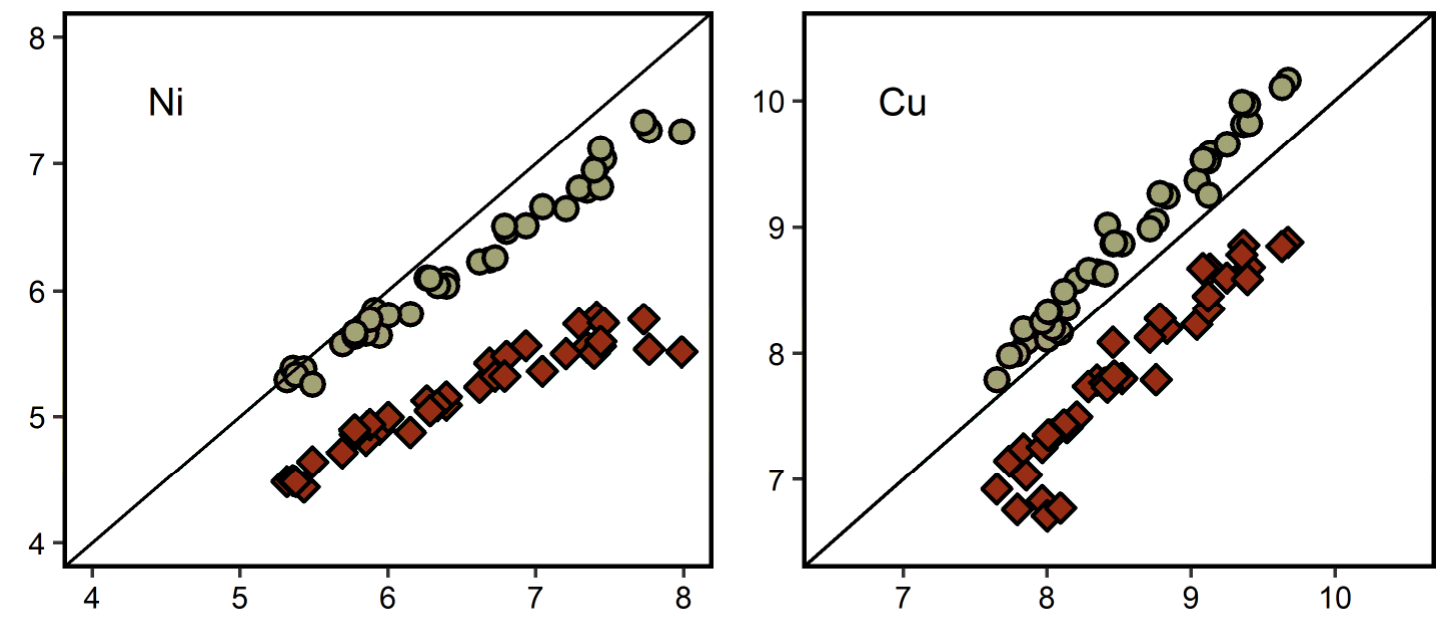

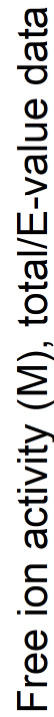
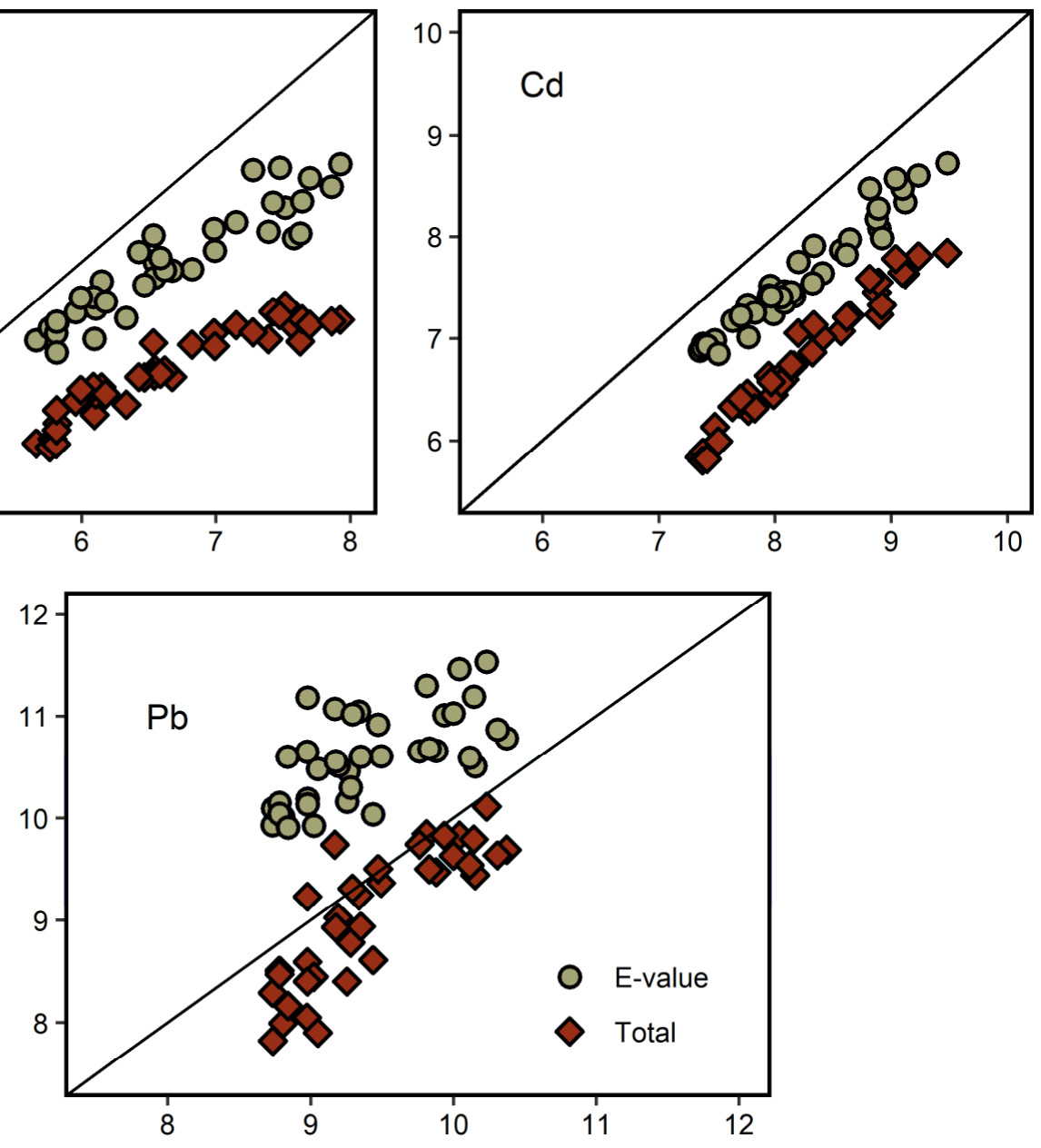

Free ion activity (M), solution data 
Figure 5
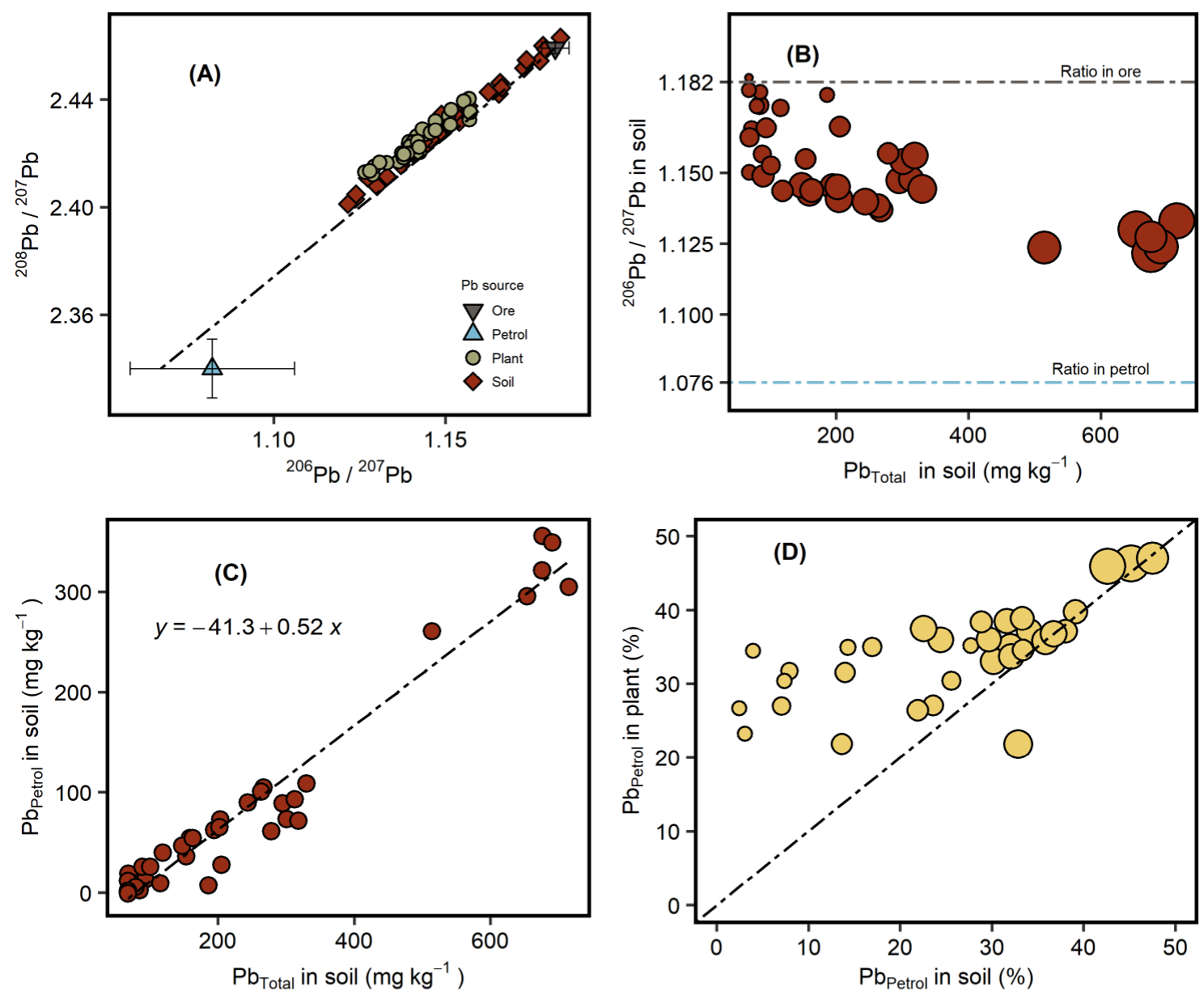
Figure 6
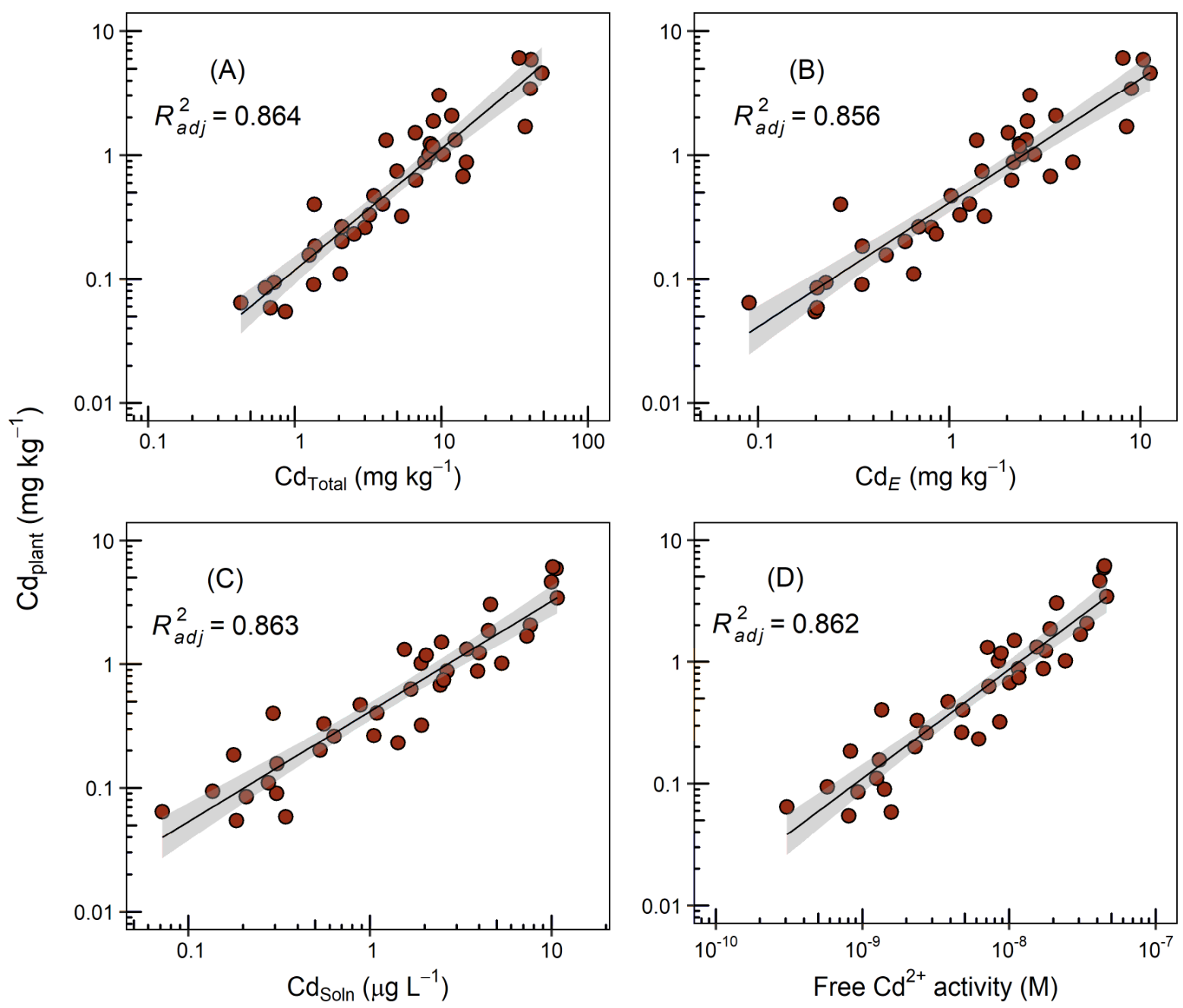


\section{The impact of long-term biosolids application (> 100 years) on soil metal dynamics}

Abdul-Wahab Mossa, Elizabeth H. Bailey, Abida Usman, Scott D. Young*, Neil M. J. Crout

School of Biosciences, University of Nottingham, Sutton Bonington Campus, Leicestershire LE12 5RD, UK

* Corresponding author, E-mail address: scott.young@ nottingham.ac.uk

\section{Study site:}

The study site is a dedicated sewage disposal site, run by a water company. The area of the site is 900 ha. The majority of the farm is grown with nine varieties of maize (Table S1); the crop silage is used for biogas production (Anaerobic Digestion).

Table S1. Maize varieties that are cropped in each field

\begin{tabular}{cc}
\hline Variety & No. of fields \\
\hline Barros & 3 \\
P7892 & 4 \\
Ambrosini & 7 \\
Anjou 277 & 2 \\
Torres & 7 \\
Valve & 1 \\
Cassilas & 2 \\
Ronaldinio & 4 \\
P7905 & 1 \\
\hline
\end{tabular}




\section{Supplementary Tables}

Soil chemical properties are shown in Table S2. A broad range of soil properties and total element concentration have been observed. The large variation in total elemental concentration in soil indicates variable biosolids application rates throughout the sampling area and over the time period that each field has been used for biosolids disposal.

Table S2. Soil organic matter (LOI), $\mathrm{pH}$ and element concentration $\left(\mathrm{mg} \mathrm{kg}^{-1}\right)$ in soil

\begin{tabular}{ccccc}
\hline & Mean & Minimum & Maximum & Std. deviation \\
\hline $\mathrm{pH}$ & 6.38 & 5.95 & 6.94 & 0.35 \\
$\mathrm{LOI}(\%)$ & 10.2 & 3.52 & 23.4 & 4.96 \\
\hline \multicolumn{4}{c}{$\left(\mathrm{mg} \mathrm{kg}^{-1}\right)$} \\
$\mathrm{Mg}$ & 6980 & 3160 & 21500 & 4260 \\
$\mathrm{~K}$ & 14400 & 4940 & 31000 & 5530 \\
$\mathrm{Ca}$ & 12700 & 3830 & 41800 & 9290 \\
$\mathrm{Al}$ & 1560 & 514 & 2500 & 521 \\
$\mathrm{~V}$ & 53.4 & 33.9 & 109 & 17.0 \\
$\mathrm{Cr}$ & 433 & 43.2 & 1670 & 440 \\
$\mathrm{Mn}$ & 565 & 152 & 1790 & 339 \\
$\mathrm{Fe}$ & 14100 & 6880 & 22800 & 3470 \\
$\mathrm{Co}$ & 11.4 & 6.72 & 16.5 & 2.47 \\
$\mathrm{As}$ & 18.7 & 8.59 & 45.6 & 8.21 \\
$\mathrm{Se}$ & 1.07 & 0.32 & 2.53 & 0.56 \\
$\mathrm{Rb}$ & 55.8 & 40.5 & 96.1 & 13.3 \\
$\mathrm{Sr}$ & 74.1 & 46.6 & 136 & 22.9 \\
$\mathrm{Mo}$ & 2.33 & 1.02 & 4.04 & 0.70 \\
$\mathrm{Ag}$ & 6.57 & 0.25 & 28.2 & 6.45 \\
$\mathrm{Sn}$ & 46.5 & 5.02 & 160 & 45.8 \\
$\mathrm{Sb}$ & 18.7 & 1.65 & 98.1 & 21.8 \\
$\mathrm{Cs}$ & 3.55 & 1.89 & 9.43 & 1.69 \\
$\mathrm{Ba}$ & 648 & 322 & 1520 & 332 \\
$\mathrm{Th}$ & 7.99 & 5.55 & 11.1 & 1.38 \\
$\mathrm{U}$ & 2.61 & 1.39 & 3.42 & 0.39 \\
\hline & & & &
\end{tabular}


Total metal concentrations in soil strongly correlated with soil organic matter content (LOI) (Table S3) suggesting a common source of contamination.

Table S3. Pearson correlation matrix for $\mathrm{M}_{\text {Total, }}$ LOI and soil $\mathrm{pH}$. Bold numbers are not significant at $\mathrm{p}<0.05$.

\begin{tabular}{|c|c|c|c|c|c|c|c|c|c|c|c|c|c|c|}
\hline $\mathrm{pH}$ & & & & & & & & & & & & & & \\
\hline-0.58 & LOI & & & & & & & & & & & & & \\
\hline-0.59 & 0.93 & Total C & & & & & & & & & & & & \\
\hline-0.69 & 0.95 & 0.89 & $\mathrm{P}$ & & & & & & & & & & & \\
\hline-0.65 & 0.96 & 0.91 & 0.97 & $\mathrm{Cr}$ & & & & & & & & & & \\
\hline 0.13 & 0.39 & 0.29 & 0.21 & 0.26 & Co & & & & & & & & & \\
\hline-0.63 & 0.95 & 0.88 & 0.96 & 0.98 & 0.31 & $\mathrm{Ni}$ & & & & & & & & \\
\hline-0.62 & 0.97 & 0.92 & 0.97 & 0.99 & 0.29 & 0.98 & $\mathrm{Cu}$ & & & & & & & \\
\hline-0.60 & 0.97 & 0.92 & 0.96 & 0.98 & 0.34 & 0.98 & 1.00 & $\mathrm{Zn}$ & & & & & & \\
\hline-0.49 & 0.85 & 0.80 & 0.81 & 0.85 & 0.31 & 0.76 & 0.83 & 0.84 & As & & & & & \\
\hline-0.61 & 0.93 & 0.83 & 0.90 & 0.92 & 0.44 & 0.90 & 0.90 & 0.91 & 0.87 & $\mathrm{Se}$ & & & & \\
\hline-0.69 & 0.86 & 0.79 & 0.90 & 0.85 & 0.33 & 0.85 & 0.85 & 0.86 & 0.73 & 0.87 & Mo & & & \\
\hline-0.62 & 0.92 & 0.87 & 0.95 & 0.96 & 0.26 & 0.99 & 0.96 & 0.96 & 0.69 & 0.86 & 0.84 & $\mathrm{Cd}$ & & \\
\hline-0.50 & 0.94 & 0.89 & 0.89 & 0.94 & 0.40 & 0.90 & 0.95 & 0.96 & 0.91 & 0.91 & 0.79 & 0.87 & $\mathrm{Ba}$ & \\
\hline-0.60 & 0.95 & 0.89 & 0.94 & 0.96 & 0.32 & 0.93 & 0.97 & 0.97 & 0.89 & 0.92 & 0.83 & 0.90 & 0.96 & $\mathrm{~Pb}$ \\
\hline
\end{tabular}


Table $\mathrm{S} 4$ shows element concentrations in the solution phase of $0.01 \mathrm{M}\left(\mathrm{CaNO}_{3}\right)_{2}$ extractions.

This extraction estimates the readily bioavailable portion of an element of interest.

Table 4. Elemental concentrations $\left(\mu \mathrm{g} \mathrm{L}^{-1}\right)$ in the solution phase of $0.01 \mathrm{M} \mathrm{Ca}\left(\mathrm{NO}_{3}\right)_{2}$

\begin{tabular}{ccccc}
\hline & Min. & Max. & Median & Mean \\
\hline $\mathrm{V}$ & 0.36 & 13.1 & 5.48 & 6.22 \\
$\mathrm{Cr}$ & 0.25 & 12.9 & 3.98 & 4.19 \\
$\mathrm{Co}$ & 0.08 & 0.72 & 0.26 & 0.3 \\
$\mathrm{Fe}$ & 2.97 & 48.9 & 15.4 & 16.8 \\
$\mathrm{Al}$ & 1.18 & 33.6 & 6.56 & 9.43 \\
$\mathrm{Mo}$ & 0.5 & 14.5 & 4.01 & 4.85 \\
$\mathrm{Cd}$ & 0.07 & 10.8 & 1.8 & 2.9 \\
$\mathrm{As}$ & 0.95 & 25 & 5.82 & 8.4 \\
$\mathrm{Mn}$ & 1.61 & 164 & 14.8 & 36.1 \\
$\mathrm{Ni}$ & 1.33 & 661 & 52.5 & 136 \\
$\mathrm{Cu}$ & 2.58 & 196 & 36.4 & 52.1 \\
$\mathrm{Zn}$ & 1.93 & 378 & 42 & 92.8 \\
$\mathrm{Sb}$ & 1.26 & 157 & 34.6 & 44.6 \\
$\mathrm{Ba}$ & 53.2 & 472 & 120 & 155 \\
$\mathrm{Sr}$ & 225 & 764 & 301 & 339 \\
$\mathrm{Se}$ & 0.55 & 2.86 & 1.16 & 1.25 \\
$\mathrm{Rb}$ & 0.1 & 4.94 & 1.52 & 1.68 \\
$\mathrm{~Pb}$ & 0.02 & 1.31 & 0.08 & 0.19 \\
\hline & & & & \\
\hline
\end{tabular}




\section{Supplementary figures}

Values of enrichment factor for different elements are shown in Figure S1. The enrichment factor was calculated as a ratio to the concentration of $\mathrm{Al}$ in soil and was normalised to the ratio in the regional background.

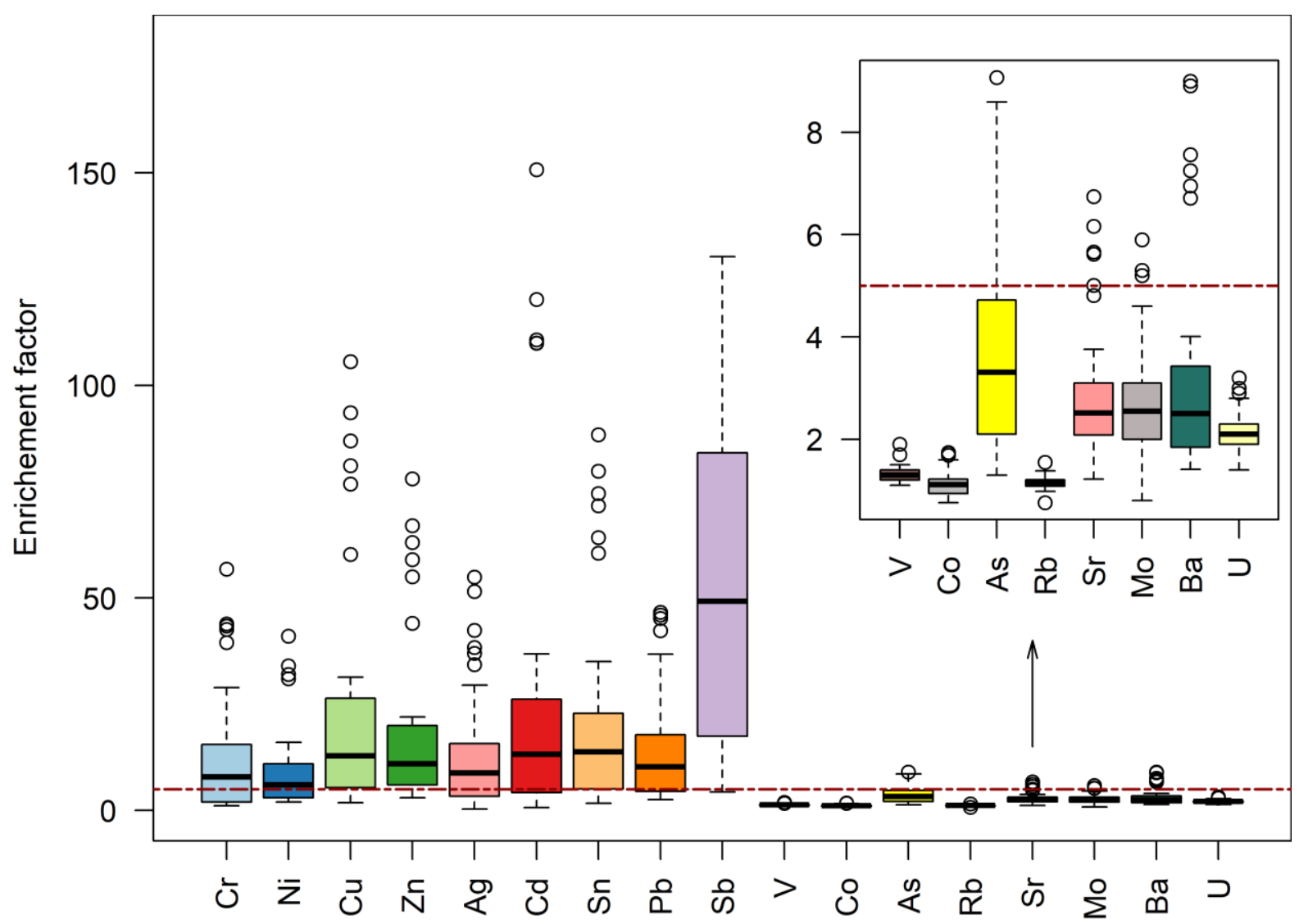

Figure S1. Boxplots of enrichment factors in the studied soils. Horizontal dashed lines represent $\mathrm{EF}$ of 5 
Figures S2-S5 show the relationships between metal concentration in plant and the metal concentration in soil measured using different estimates of metal bioavailability in soil. All metal bioavailability indices produced good predictions of $\mathrm{Ni}, \mathrm{Cu}$, and $\mathrm{Zn}$ concentration in plant, explaining more that $70 \%$ of the variation in the concentration in plant (Figs S2-S4).
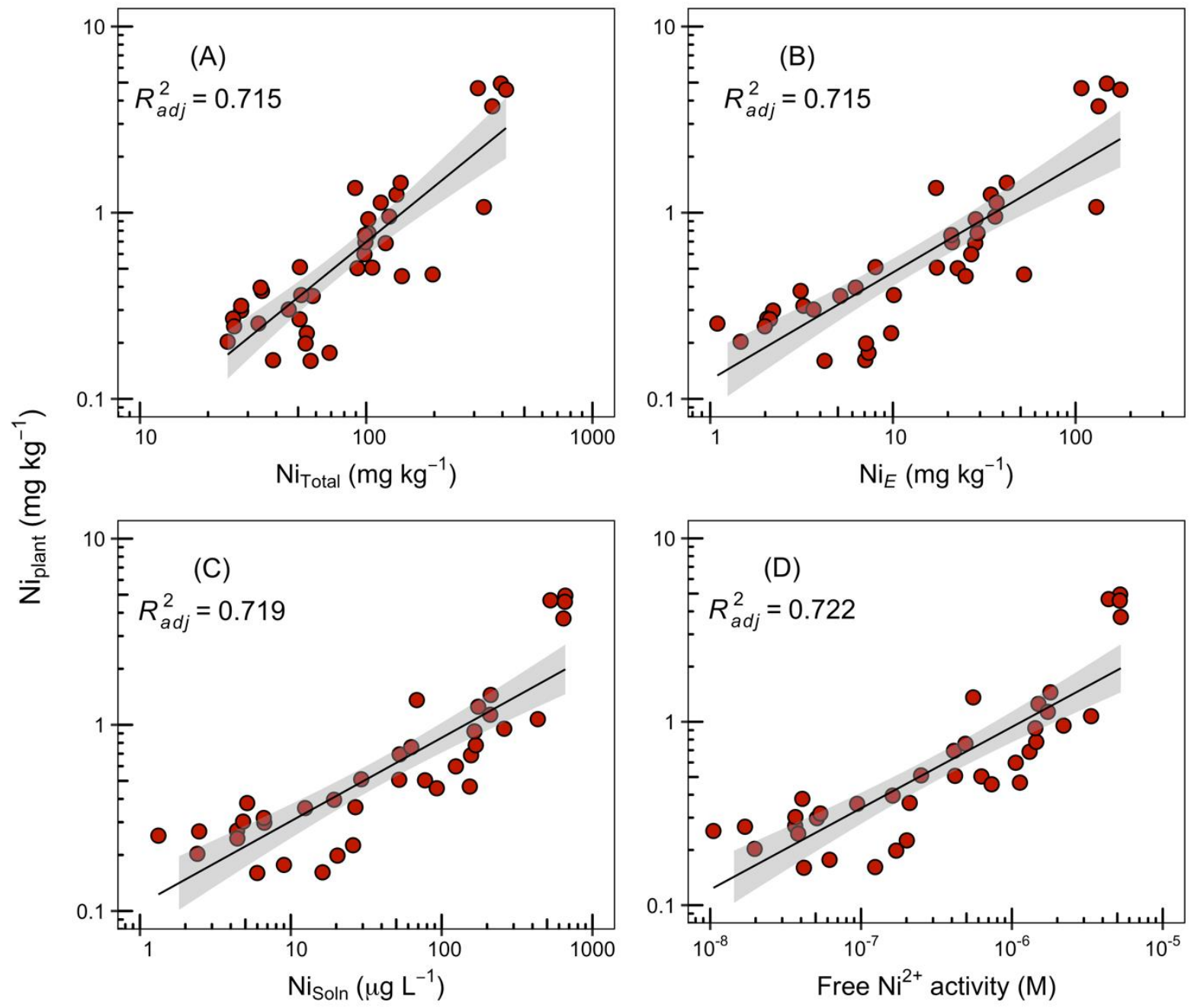

Figure S2. Relationships between Ni concentration in maize plants and $\mathrm{Ni}$ concentration in soil. The latter included (A) total $\mathrm{Ni}_{\text {Total }}$, (B) labile $\mathrm{Ni}_{\mathrm{E}},(\mathrm{C}) \mathrm{Ni}_{\text {Soln }}$, (D) $\mathrm{Ni}^{2+}$ activity. The solid lines represent a linear regression fit. Grey shaded areas represent $95 \%$ confidence interval around fitted values. 

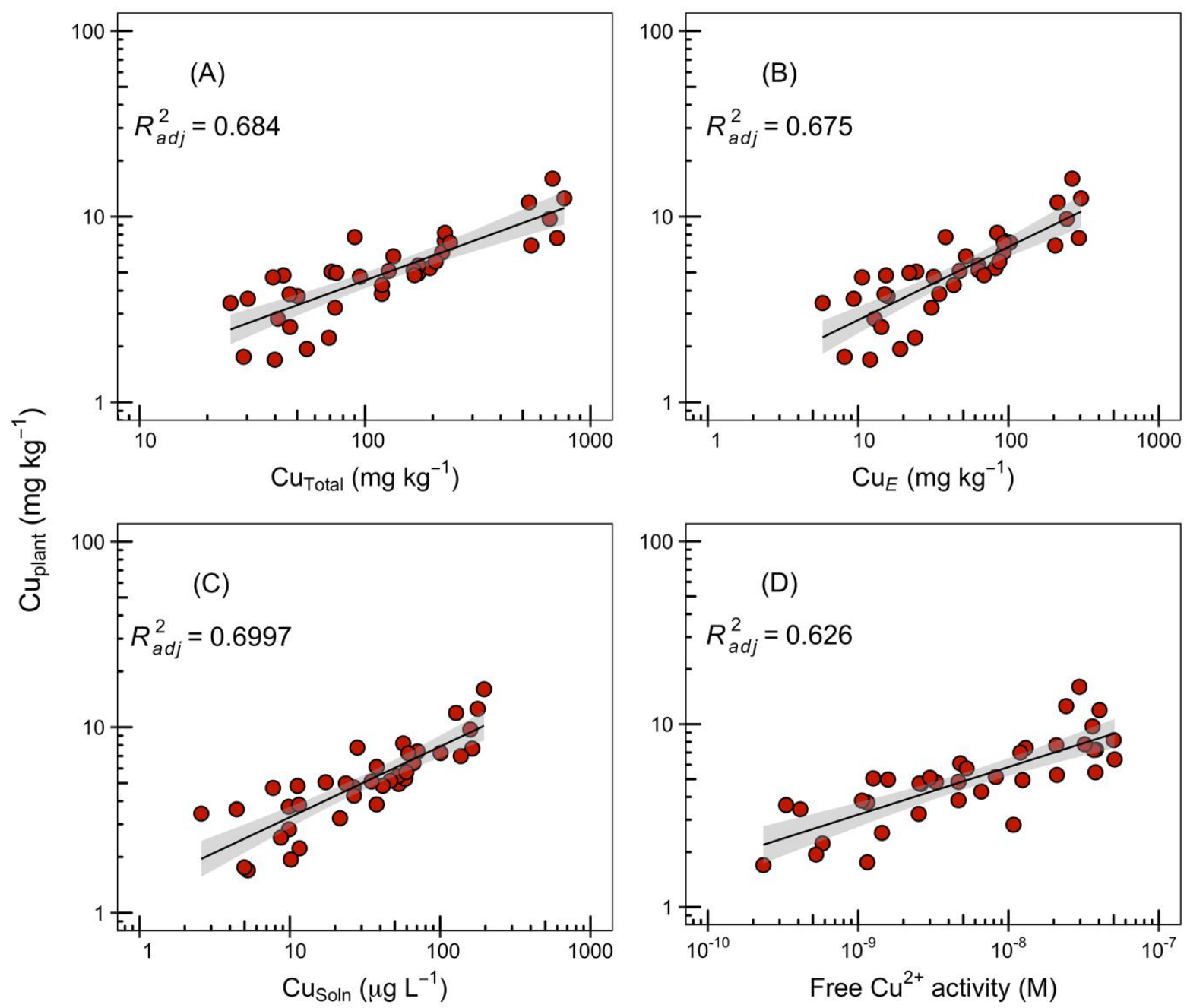

Figure $\mathrm{S} 3$. Relationships between $\mathrm{Cu}$ concentration in maize plants and $\mathrm{Cu}$ concentration in soil. The latter included (A) total $\mathrm{Cu}_{\text {Total }}$, (B) labile $\mathrm{Cu}_{\mathrm{E}}$, Cusoln, (D) $\mathrm{Cu}^{2+}$ activity. The solid lines represent a linear regression fit. Grey shaded areas represent $95 \%$ confidence interval around fitted values. 

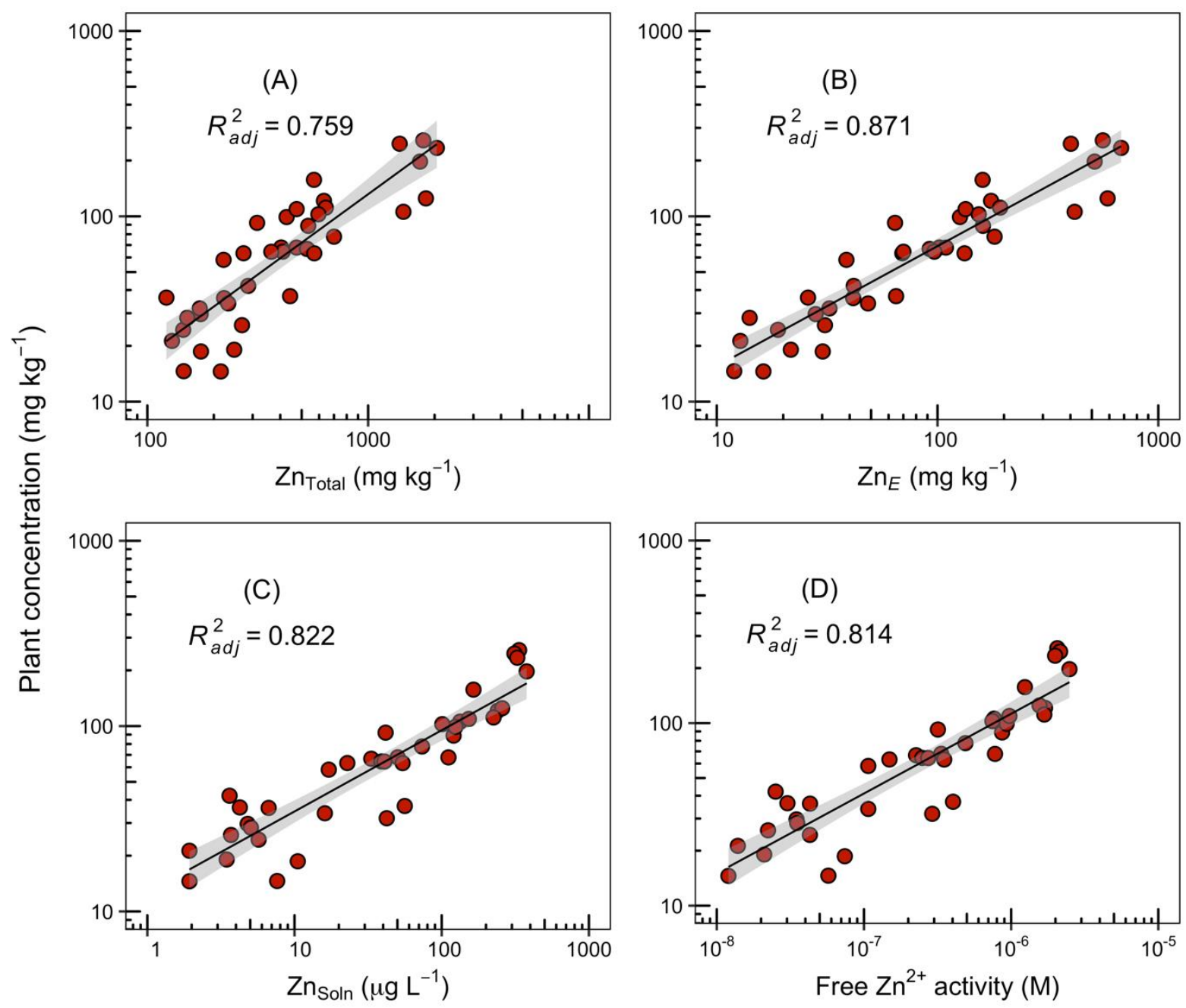

Figure S4. Relationships between $\mathrm{Zn}$ concentration in maize plants and $\mathrm{Zn}$ concentration in soil. The latter included (A) total $\mathrm{Zn}_{\text {Total }}$, (B) labile $\mathrm{Zn}_{\mathrm{E}}$, (C) $\mathrm{Zn}_{\text {Soln }}$, (D) $\mathrm{Zn}^{2+}$ activity. The solid lines represent a linear regression fit. Grey shaded areas represent $95 \%$ confidence interval around fitted values. 
In the case of $\mathrm{Pb}$ (Fig. S5) however, all metal bioavailability measures resulted in weak relations, albeit significant, with $\mathrm{Pb}$ concentration in maize plants, where only a maximum of $34 \%$ of the variation was accounted for. Contamination of the crop by soil-derived dust probably accounted for most of the $\mathrm{Pb}$ measured in the plant.
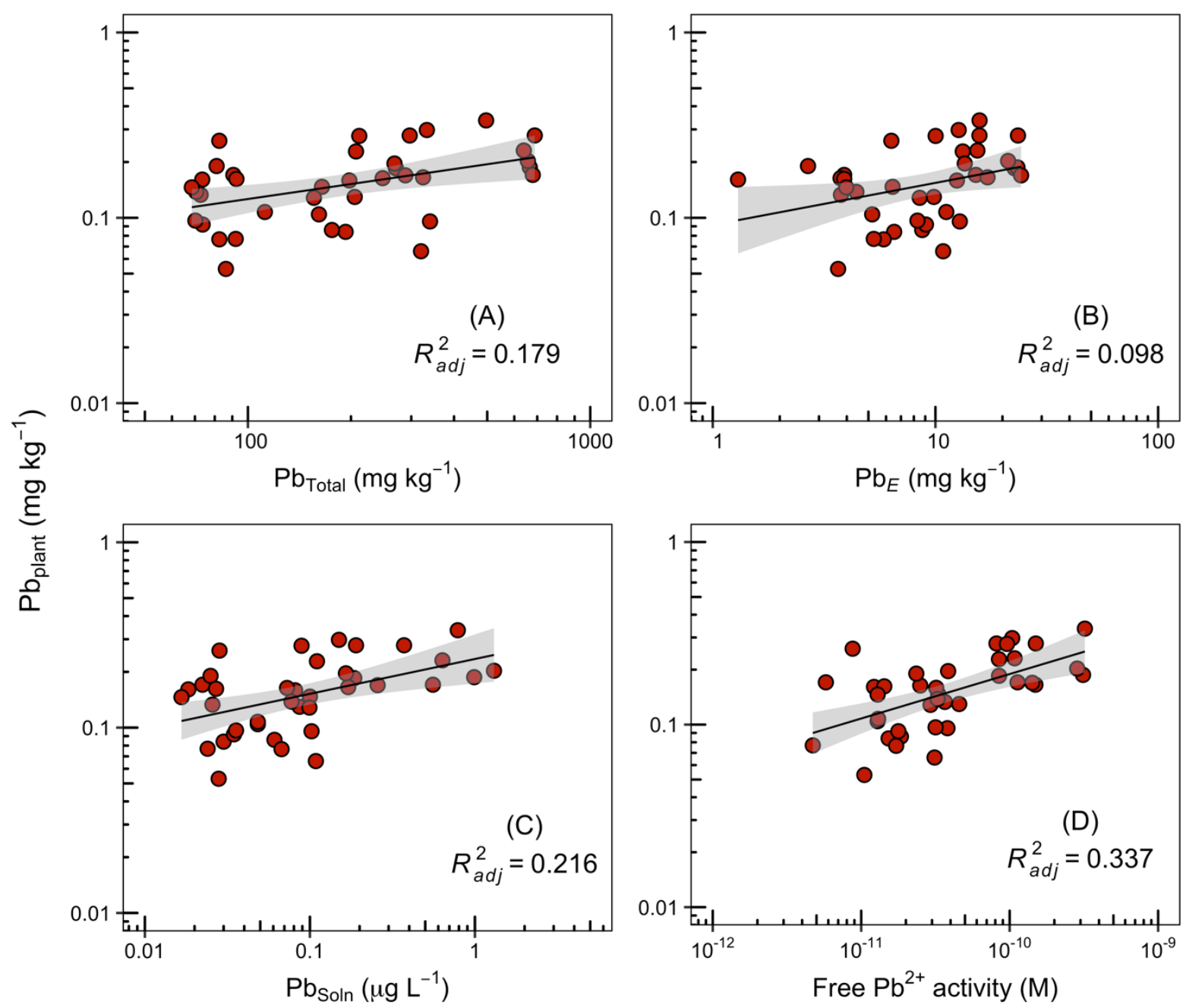

Figure $\mathrm{S} 5$. Relationships between $\mathrm{Pb}$ concentration in maize plants and $\mathrm{Pb}$ concentration in soil. The latter included (A) total $\mathrm{Pb}_{\text {Total }}$, (B) labile $\mathrm{Pb}_{\mathrm{E}},(\mathrm{C}) \mathrm{Pb}_{\mathrm{Soln}}$, (D) $\mathrm{Pb}^{2+}$ activity. The solid lines represent a linear regression fit. Grey shaded areas represent $95 \%$ confidence interval around fitted values. 